\title{
'N PRAGMATIESE BENADERING TOT DIE ONTWIKKELING VAN 'N GEWEEGDE AANSOEKVORM
}

\author{
L.J. FICK \\ DEPARTEMENT BEDRYFSIELKUNDE \\ UNIVERSITEIT VAN STELLENBOSCH
}

\begin{abstract}
SUMMARY
Simplified procedures for the development of a weighted application blank to combat labour turnover of co loured employees in the clothing industry are outlined and discussed
\end{abstract}

Dit gebeur dikwels dat 'n organisasie spesifieke personeel probleme soos byvoorbeeld arbeidsomset, afwesigheid, dislojaliteit, ensovoort onder 'n spesifieke groep van sy personeel ondervind. In die langtermyn sal die regstelling van hierdie probleme verkieslik in die bepaling van die oorsake van die probleme, die bestudering daarvan en die moontlike uitskakeling daarvan, geleë wees. Soms mag hierdie probleem (of probleme) egter redelik akuut wees en kan die uitskakeling van die simptome van die probleem (bv. omset, afwesigheid, ens.) op die korttermyn voorrang geniet.

Arbeidsomset of afwesigheid is egter nie altyd slegs 'n simptoom van diepliggende probleme in die organisasie nie. Sommige individue is skynbaar meer geneig daartoe as ander. Die basiese oorsake van hulle gedrag is moontlik in die individu self gesetel, maar vir die organisasie is die feit dat tussen $10 \%$ en $20 \%$ werknemers gewoonlik verantwoordelik is vir tussen $70 \%$ en $80 \%$ van byvoorbeeld die totale afwesigheid in die organisasie, die belangrikste aspek van die probleem (Flippo, 1971).

Koste verbonde aan afwesigheid en arbeidsomset kan baie hoog wees. Kretchmer (1966) het byvoorbeeld gevind dat die koste van een vervanging (een omsetting) vir loonpersoneel in die fabrieksektor van Suid-Afrika so hoog as R80 000 is.

Enige besparing in hierdie koste sal direk in die organisasie se wins weerspieël word. Dit is egter ook waar dat die direkte koste verbonde aan afwesigheid of arbeidsomset nie altyd die hoogste is nie. Indirekte kostes en ook die negatiewe invloed wat hierdie personeelprobleme op ander werkers en die organisasie se beeld na buite het, mag bewys om 'n groter nadeel as die direkte koste te wees. 
Een moontlike benadering om die simptome van die probleem te verlig, is om tydens die indiensnemingsproses diegene wat meer vatbaar vir die probleme (bv. afwesigheid) is, te identifiseer en op 'n vroeë stadium van die seleksieproses uit te skakel. Baie organisasies word egter deur die omvang van die werk verbonde aan die ontwikkeling van 'n spesifieke tegniek om hierdie individue te identifiseer, ontmoedig. Die oortuiging mag soms in die personeeldepartement gehandhaaf word dat die bedieningsveld en die effektiewe leeftyd van sodanige tegniek onvoldoende is om die koste en tyd verbonde aan die ontwikkeling daarvan te regverdig. Met ander woorde dat die groep waarbinne die probleem manifesteer, te klein is of dat die relatief snelle veranderings wat in die onderneming plaasvind, tot gevolg het dat die tegniek vinnig verouder en kort-kort aangepas moet word.

\section{DOEL}

Die doel van hierdie artikel is om, na aanleiding van 'n studie gedoen in die klerasiebedryf (waartydens 'n geweegde aansoekvorm vir die bekamping van arbeidsomset onder gekleurde werknemers ontwikkel is) 'n vereenvoudigde, vinnige en pragmatiese benadering vir die ontwikkeling van 'n geweegde aansoekvorm sistematies aan te bied. Die gedagte is dat sodanige vereenvoudigde prosedure vir die ontwikkeling van 'n tegniek om individue te identifiseer wat meer vatbaar vir arbeidsomset (of afwesigheid) is, die nadele van koste en tyd verbonde aan die ontwikkeling grootliks sal elimineer en dat klerklike personeel vir die ontwikkeling en instandhouding van die tegniek gebruik kan word.

\section{WAT IS ‘ $N$ GEWEEGDE AANSOEKVORM?}

Die geweegde aansoekvorm (G.A.V.) het sy ontstaan uit die gedagte dat sekere biografiese inligting soos byvoorbeeld ouderdom, geslag, vorige beroep en huwelikstaat, belangrike aspekte van 'n persoon se totale agtergrond verteenwoordig en dus bruikbaar vir keuringsdoeleindes kan wees (Goldsmith, 1922). Sommige van die aspekte in 'n persoon se totale agtergrond mag nou verwant wees aan sukses of mislukking in 'n onderneming. In die verlede het verskeie studies daarop gedui dat sekere inligting wat deur middel van 'n aansoekvorm verkry word, voorspellingswaarde besit en suksesvol vir seleksiedoeleindes aangewend kan word (Bills, 1939 en Evertt, 1939). Daar is gevind dat persoonlike faktore soos byvoorbeeld geslag of vorige ondervinding positief korreleer met gewensde 
werknemersgedrag soos lengte van diens, verkoopsvolume en hoë merietebeoordeling in 'n organisasie (Kerr en Martin, 1950).

Daar moet dus 'n manier gevind word om te bepaal watter faktore van 'n persoon se totale biografiese agtergrond betrekking het op die besondere kriterium wat van belang is. Die geweegde aansoekvormtegniek identifiseer daardie items op aansoekvorms wat differensieer tussen gewensde en ongewensde werknemers ten opsigte van die bepaalde kriterium. Deur die bepaling van die voorspellingswaarde van elke afsonderlike item op die aansoekvorm, is dit dan moontlik om numeriese gewigte aan elke moontlike antwoord toe te ken. Vervolgens is dit nodig om die som van gewigte vir elke item vir elke individu te bereken en 'n minimum totale telling daar te stel. Die gebruik van hierdie minimum-totale telling in seleksie sal verseker dat die maksimum aantal ongewensde kandidate geëlimineer word met 'n minimum verlies van gewensde kandidate.

Die G.A.V. moet ontwikkel word na aanleiding van die spesifieke doel waarvoor dit gebruik gaan word. Met ander woorde, as die probleem arbeidsomset is, moet daardie items uit 'n persoon se totale biografiese agtergrond wat hoog korreleer met lang- of korttermyn diens, geselekteer word. As die probleem egter produktiwiteit of afwesigheid is, moet biografiese items identifiseer word wat 'n sterk verband daarmee toon.

Daar kan egter ook gebruik gemaak word van 'n kombinasie van G.A.V.'s om ten opsigte van twee of meer doelstellings soos byvoorbeeld langtermyn diens en produktiwiteit te voorspel. Die gebruik van die G.A.V. kan dus baie uitgebrei word as die kriterium slegs telkens aangepas word by die nuwe doel.

Die geweegde aansoekvormtegniek is alreeds vir 'n wye reeks doelstellings gebruik. Daar is baie voorbeelde van navorsingstudies in die literatuur van die gebruik van die G.A.V. om afwesigheid en arbeidsomset vir verskillende groepe werknemers te voorspel of te bekamp (Minor, 1958 en Mosel en Wade, 1951). Kerr en Martin (1949) gebruik die G.A.V. om werksukses te voorspel. McGrath (1961) se navorsing lewer bewys dat die gebruik van die G.A.V. die beoordeling van ' $n$ individu se kredietwaardigheid baie bevorder. Smith, Albright, Glennon en Owens (1961) gebruik die G.A.V. vir die voorspelling van navorsingsbevoegdheid en skeppendheid. Albright en Glennon (1961) vind positiewe korrelasies tussen die persoonlike geskiedenis van wetenskaplikes en hul beroepsprestasies. Alhoewel moord nie as werksgedrag beskou kan word nie, het Kahn (1965) biografiese items gebruik in 'n poging om die gedrag van moordenaars te voorspel. Harrell (1960) maak gebruik van biografiese items vir die seleksie van verkoopspersoneel. Tanofsky, Shepps en O'Neill (1969) 
voorspel sukses as versekeringsagent met behulp van biografiese voorspellers. Anastasi en Schaefer (1969) bepaal die verwantskap tussen biografiese gegewens en artistiese en literêre skeppendheid by volwasse dames. Ehrle (1964) maak gebruik van biografiese data om die sukses in beroepsrehabilitasie te voorspel. Kavangh en York (1972) vind beduidende verwantskappe tussen biografiese items en werksprestasie van middelvlak bestuurders. Voorbeelde van die gebruik van die biodatabenadering om verskillende kriteria te voorspel, word op bykans alle gebiede gevind.

Die gebruik en verfyning van biografiese data in die sielkunde het in die afgelope twee dekades baie aandag ontvang. 'n Mylpaal in dié ontwikkeling was die "Conference on the use of Biographical Data in Psychology", wat teen die middel van die sestiger jare in Amerika gehou is (Henry, 1966). Tydens die konferensie is gepoog om die redes waarom so min op die gebied van die biografiese benadering na die Tweede Wêreldoorlog gedoen is, te bepaal. Daar is besluit om 'n aksie-komitee saam te stel en dat die Richardson Foundation die navorsing op die gebied van die biodatabenadering sal borg. Sedertdien is "A Catalog of Life History Items" deur hul gepubliseer wat uit 114 bladsye bruikbare biografiese items bestaan (Glennon, Albright en Owens, 1966).

Hierdie daadwerklike poging van die American Psychological Association het as impetus gedien vir baie navorsing op die gebied soos byvoorbeeld die werk van Goldstein (1971) wat die eerlikheid waarmee aansoekvorms voltooi word, ondersoek het en die navorsing van Asher (1972) wat besin oor die wyse waarvolgens die biodata-itembenadering verbeter kan word. Huidige navorsing op die gebied van biodataseleksietegnieke beskik oor die kenmerke van gesofistikeerde toetsontwikkeling en validasie.

\section{PROSEDURE}

Die kritiese faset in die ontwikkeling van 'n G.A.V. wat ondernemings mag afskrik, is waarskynlik die bepaling van die verwantskappe tussen biografiese items en die kriterium asook die ontwikkeling van gewigte wat aan elke item gekoppel moet word. In die volgende prosedure wat vir die ontwikkeling van die G.A.V. aanbeveel word, sal vereenvoudigde stappe vir die bepaling van gewigte voorgehou word: (a) Keuse van kriterium. (b) Die monster en identifikasie van kriteriumgroepe. (c) Keuse van biografiese items vir ontleding. (d) Opsomming van vraelysgegewens. (e) Bepaling van itemgewigte. (f) Toekenning van gewigte aan die validasiegroepe. (g) Konstruksie van die G.A.V. 
Hier volg nou 'n kort uiteensetting van elkeen van bogenoemde stappe:

\section{KEUSE VAN KRITERIUM}

Die seleksie van die kriterium is 'n baie belangrike aspek vir die ontwikkeling van die G.A.V. Die meeste wat van die G.A.V. verwag kan word, is om die kriterium (dienstermyn) wat gebruik is in die ontwikkeling, te voorspel. As hierdie kriterium onbetroubaar of ongeldig is, kan daar nie van die G.A.V. verwag word om 'n positiewe bydrae tot die seleksiebattery te lewer nie. Die G.A.V. kan dus slegs so akkuraat wees as wat die kriterium is waarop besluit is.

Die kriterium waarop besluit word sal afhang van die doel wat die G.A.V. moet dien. As die doel die voorspelling van werksprestasie is, mag merietebeoordeling as kriterium gekies word; as die doel die voorspelling van afwesigheid is, mag die frekwensie van afwesigheid as kriterium dien, ensovoorts. In die besondere studie wat in die klerasiebedryf uitgevoer is om arbeidsomset met behulp van die G.A.V. te voorspel, was die keuse van die kriterium relatief selfbepalend en eenvoudig, daar die kriterium "dienstermyn" is. Lengte van diens is objektief en kan maklik in numeriese waardes uitgedruk word. Die belangrike probleem in hierdie geval sal die bepaling van kriteriumgroepe wees. (Voorts word slegs gekonsentreer op die voorbeeld van arbeidsomset om die ontwikkeling van die G.A.V. te illustreer.)

\section{DIE MONSTER EN IDENTIFIKASIE VAN KRITERIUMGROEPE}

Die universum in hierdie studie is 890 gekleurde werknemers wat gedurende die periode Junie 1966 tot Junie 1968 in 'n klerasiefabriek werksaam was. Die monster is getrek volgens Meredith (1962) se "Tables of Random Numbers" om sodoende die monster wat in hierdie studie gebruik is, naamlik 150 daar te stel. Uit hierdie 150 is twee groepe van 50 elk gebruik as eksperimentele groepe waarop die studie uitgevoer is en twee groepe van 25 elk is gebruik vir kruisvalidasiedoeleindes. 'n Skematiese voorstelling word in Figuur 1 weergegee.

\section{Identifikasie van kriteriumgroepe}

Die totale populasie is beskou as twee afsonderlike dele (vergelyk Figuur 1) vir die doeleindes van monstertrekking. 'n Hoë en lae kriteriumgroep word onderskei - 'n hoë krite- 
riumgroep wat die gewensde werknemers verteenwoordig ten opsigte van dienstermyn (lang dienstermyn) en 'n lae kriteriumgroep wat op sy beurt die ongewensde werknemers ten opsigte van dienstermyn (kort dienstermyn) verteenwoordig. Uit elkeen van hierdie dele van die universum is daar 'n monster van 75 elk getrek.

Elke kriteriumgroep is vervolgens verdeel in 'n eksperimentele groep en 'n validasiegroep (Figuur 1). Die eksperimentele groepe word gebruik om die biografiese items wat voldoende differensieer tussen gewensde en ongewensde werknemers, te identifiseer en te weeg. Daarenteen word die validasiegroepe gebruik om die geldigheid en bruikbaarheid van die geweegde aansoekvorm te toets en om die afsnytelling of gewig te bepaal vir latere aanwending van die tegniek vir keuring.

Totale Arbeidspopulasie in Onderneming

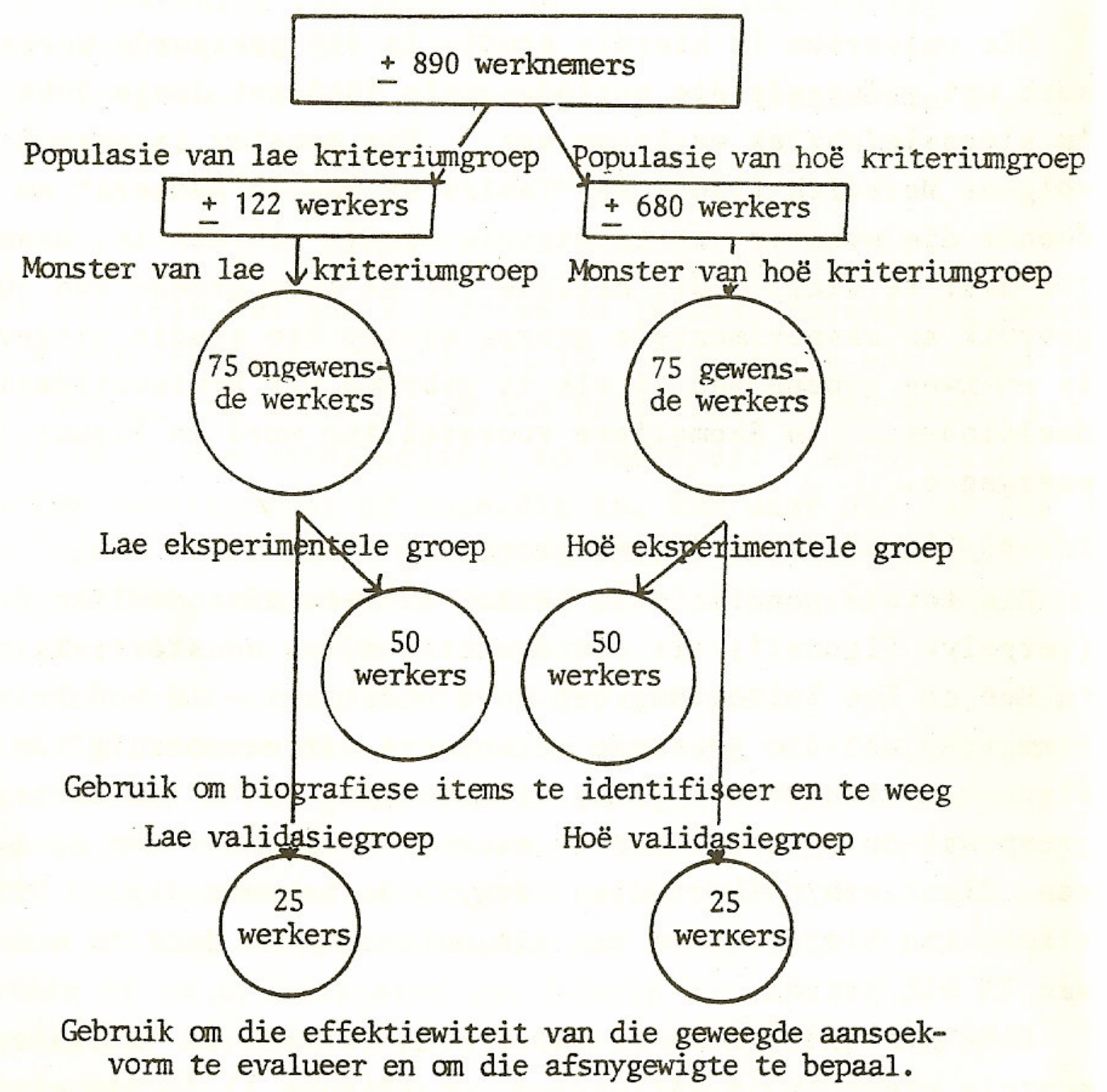

Figurur 1. Skematiese voorstelling van universum en monstertrekking 
England (1961) beveel aan dat daar 'n vaste ratio van 2 tot 1 tussen die grootte van die eksperimentele- en validasiegroepe behou moet word. Na aanleiding hiervan is die monster in hierdie studie verdeel om 50 werknemers in die eksperimentelegroepe en 25 werknemers in die validasiegroepe te bevat.

\section{Periode waartydens werknemers wat in universum gebruik is by die organisasie werksaam} was

Met die seleksie van die kriteriumgroepe in die geval waar die kriterium dienstermyn is, het daar verskeie probleme opgeduik. So byvoorbeeld moet daar bepaal word hoe ver terug, kronologies gesien, daar gegaan kan word met die trek van werknemers wat reeds die diens verlaat het. Daar moet ver genoeg teruggegaan word om 'n voldoende populasie van diensverlaters te verkry om 'n geskikte monsteromvang daar te stel. Tog kan daar weens veranderings in die arbeidsmark en ekonomiese toestande nie onbepaald teruggegaan word nie. Probleemareas wat in dié verband oorweeg is, is die ontruiming van Bantoe werknemers uit die Wes-Kaapse gebied (die omgewing waar die klerasiefabriek geleë is), die blankverklaring van gebiede in die onmiddellike omgewing van die organisasie (daar dit 'n invloed op die arbeidsaanbod kon hê), die moontlikheid dat woonstelblokke vir kleurlinge in die onmiddellike omgewing van die klerasiefabrieke opgerig kan word, ensovoorts.

\section{Vasstelling van afsnypunte tussen "lang-en korttermyn" werknemers}

'n Verdere belangrike probleem waaraan aandag geskenk moet word by die seleksie van kriteriumgroepe, is waar om die afsnypunt tussen "lang- en korttermyn" werknemers te plaas. Om hierdie probleem op te los is die "diensverlaters-populasie" eers grafies voorgestel soos in Figuur 2 uitgebeeld. Uit hierdie grafiek blyk dit dat 'n groot getal werknemers (122 uit die moontlike 337 "diensverlaters van die afgelope twee jaar) die organisasie binne die eerste drie maande verlaat het. Die boonste grens vir die bepaling van die lae kriteriumgroep (korttermyn of ongewensde werkers) is na aanleiding hiervan op drie maande geplaas. Verder is daar gevind dat ' $n$ werknemer wat vir ' $n$ termyn langer as een jaar in diens was, geneig is om vir ' $n$ lang periode in diens te bly. Hierbenewens het werkers wat langer as een jaar diens het in die klerasiebedryf, reeds 'n afdoende bydrae gelewer om die indiensnemings- en opleidingskoste vir die posisies waarvoor hulle in diens geneem is, te regverdig. Die onderste grens vir die bepaling van die hoë kriteriumgroep (langtermyn werkers of gewensde werkers) is dus op een jaar gestel. 


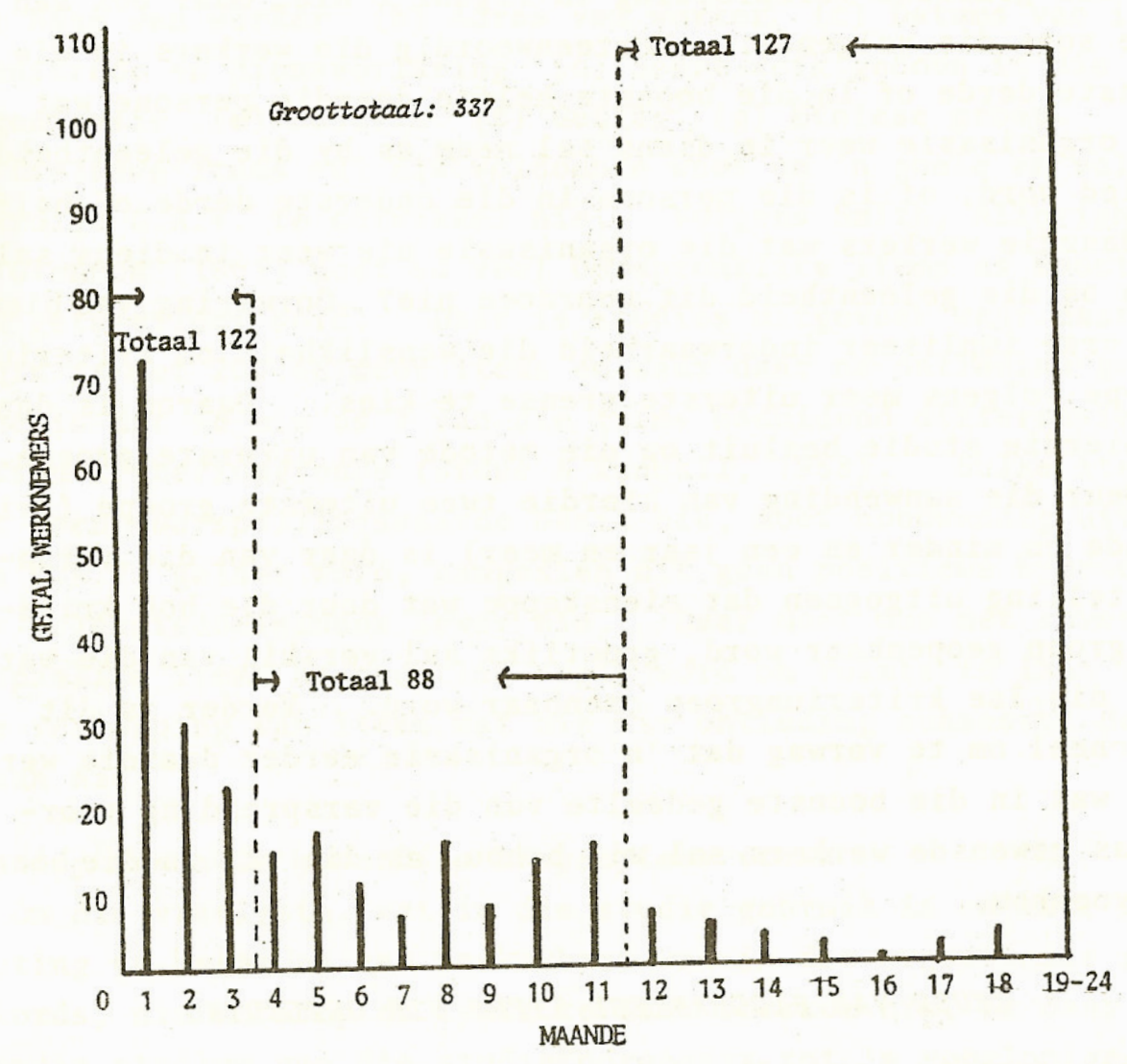

Figuur 2. Verspreiding van diensverlaters oor twee jaar.

Werknemers wat vir meer as drie maande en minder as een jaar in diens was, is geheel en al buite rekening gelaat om sodoende die aandag pertinent te fokus op die twee uiterste groepe.

Daar is verskeie maniere om individue te verdeel in kriteriumgroepe. Daar is egter geen enkele benadering wat deurgaans in alle situasies van toepassing is nie. In sommige studies (Yoder, 1958) waar twee kriteriumgroepe opgestel is, word die monster in ' $n$ boonste en onderste helfte verdeel. Ander verdeel weer die monster in 'n boonste derde en 'n onderste derde (England, 1961) of in 'n boonste kwart en 'n onderste helfte of kwart (Yoder, 1963). Voordat daar egter op enige metode besluit is, is daar oorweging geskenk nie alleen aan die grafiese verspreiding in Figuur 2 nie, maar ook aan vrae soos die volgende: Verteenwoordig die werkers in die boonste derde of in die boonste helfte daardie persone wat die organisasie weer in diens sal neem as hy die geleentheid gebied word, of is die persone in die onderste derde of helfte daardie werkers wat die organisasie nie weer in diens sal neem as die geleentheid dit voordoen nie? Oorweging van hierdie vrae impliseer inderwaarheid die 
wenslikheid om kriteriumgroepe volgens meer uiterste grense te kies. Daarom is daar in hierdie studie besluit op die metode van uiterste groepe.

Deur die aanwending van hierdie twee uiterste groepe (drie maande en minder en een jaar en meer) is daar van die veronderstelling uitgegaan dat eienskappe wat deur die hoe kriteriumgroep geopenbaar word, grootliks sal verskil van die wat deur die lae kriteriumgroep openbaar word. Verder is dit rasioneel om te verwag dat 'n organisasie eerder daardie werkers wat in die boonste gedeelte van die verspreiding voorkom as gewensde werkers sal wil behou, as die wat in die boonste voorkom.

\section{KEUSE VAN BIOGRAFIESE ITEMS VIR ONTLEDING}

Die soort en hoeveelheid items wat ontleed kan word, hang grotendeels af van die gegewens vervat in die organisasie se bestaande aansoekvorm, asook addisionele inligting wat uit ander persoonlike rekords in die onderneming verkry kan word. Die meeste organisasies sal slegs hierdie inligting gebruik as hul teen die laagste moontlike koste 'n G.A.V. wil ontwikkel.

By die organisasie waar hierdie studie uitgevoer is, was slegs die volgende sewe items in bestaande rekords beskikbaar: (a) Naam van werker (b) Adres van werker (c) Datums van indienstrede en diensverlating (d) Soort werk gedoen in die organisasie (e) Salaris (f) Geslag (g) Etniese groep.

Dié sewe items sal nie voldoende wees om 'n goeie en volwaardige G.A.V. te ontwikkel nie. Volgens Smith, Allbright en Glennon (1961) moet so veel oorspronklike items as moontlik getabelleer word. Daar is studies uitgevoer waar daar begin is met 200 en meer items en waar daar na ontleding gevind is dat so min as 7 van die items beduidend differensieer tussen kriteriumgroepe (Stone \& Kendall, 1958). Sulke items wat geen voorspellingswaarde besit nie, moet noodwendig uit die G.A.V. gelaat word, aangesien dit geen positiewe bydrae vir seleksiedoeleindes lewer nie. Daar moet dus met soveel toepaslike items as moontlik begin word om ruimte te laat vir die verwerping van items wat nie die ontleding suksesvol deurstaan nie.

\section{Sifting van alle moontlike biografiese items}

Om die vraelyste, wat in die studie gebruik is om meer inligting te bekom as wat beskikbaar was in die organisasie se rekords, nie so lomp en lywig te laat voorkom nie, is daar 
op hierdie stadium van die studie oorgegaan tot ' $n$ voorlopige sifting van alle moontlike biografiese items wat uit verskillende bronne verkry is. (Vir hierdie doel kan daar met vrug van "A Catalog of Life History Items", waarna reeds vroeër verwys is, gebruik gemaak word.) Net items wat 'n sterk oënskynlike verwantskap met die hoë of lae kriteriumgroepe getoon het, is by die vraelys ingesluit. Die opstel van so 'n vraelys het die verdere voordeel dat dit uniformiteit in onderhoude en antwoorde in die hand werk. Daar is uiteindelik besluit op ' $\mathrm{n}$ vraelys bestaande uit die 24 items soos in Tabel 1 weergegee.

\section{Indeling van antwoorde op items}

Die indeling van die antwoord-moontlikhede vir elke item wat geselekteer is, is versigtig vooraf gemaak van gegewens uit studies wat reeds in die klerasiebedryf uitgevoer is soos byvoorbeeld "Labour Turnover in the Clothing Industry" (Cilliers, 1968), inligting wat in die organisasie se rekords gevind is, asook van steekproefonderhoude met indiwidue uit die hoë en lae kriteriumgroepe.

Steekproefonderhoude. Om die indeling van antwoord-moontlikhede op elke biografiese faktor deur te voer, is daar, soos hierbo genoem, gebruik gemaak van verskillende bronne vir die verkryging van informasie op die gebied. Daar is egter veral klem gelê op die steekproefonderhoude.

Vyftien indiwidue is op toevallige wyse gekies in die hoë en lae kriteriumgroepe. Hierdie vyftien persone moes informasie verskaf op al 24 biografiese faktore wat gekies is vir opname in die vraelys.

Alhoewel daar voor die werklike konstruksie van die vraelys versigtige studies uitgevoer is, beteken dit nie dat die indeling soos op die oorspronklike vraelys, die beste is en daar geen beter indeling moontlik is nie. Om hierdie rede is die klassifikasie so breed as moontlik binne die raamwerk van die voorafgaande tentatiewe studie gemaak. Dit verskaf voldoende ruimte vir die latere herklassifikasie van die itemkategorie om sodoende die beste resultate van die roudata te verkry. 
TABEL 1

Vraelys

Naam: $\ldots \ldots \ldots \ldots$

1. Geslag

Manlik

Vrculik

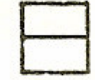

2. Ouderdom

$\begin{array}{ll}15-20 & \text { jaar } \\ 21-26 & " \\ 27-32 & " \\ 33-38 \quad " \\ 39-44 \quad " \\ 45-50 \quad " \\ 50+\end{array}$

3. Gertroude stact

Getroud

Ongetroud

Geskei

Hedurvee/wewenaar

ongetroud met

kinders

4. Boeveetheid jare getrond Minder as 1 jaar

1-2 jaar

3-5 jaar

$6+$

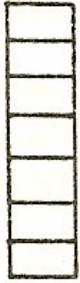

5. Afhankitkes (Kinders en andersins)

Geen

$1-3$

$4+$
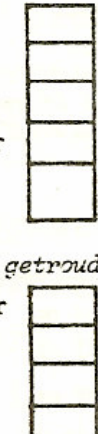

6. Gesondheid

Goed

Redelik

Swak
7. Sehuising

Besit eie huis of betaal ff

Hurr 'n huss

Huur 'n kamer

Loseer

Bly by ouers

8. Afstand van huis na werk

Minder as $1 \mathrm{my} 1$

2-4 my1

$5-7$ "

8-10"

$11-13$ "

14-16"

$17+$

9. Koste van vervoer

Geen koste per week

$9 c$ en minder

$10 c-49 c$

$50 c-99 c$

R1.00-R1.49

$\mathrm{R} 1.50-\mathrm{R} 2.00$

10. Hoeveetheid adresveranderings afgelope 2 jaco

Geen

1

2-3
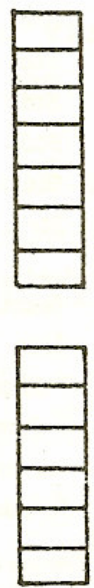

11. Etriese groep (Ras) (Bevolkingsgroep)

Kleurling

Maleier

Bantoe

Ander 
TABEL 1 (VERVOIG)

12. Aantal broodurinere

Net u

Twee

Drie

Vier

Mecr as vier

i3. Geboortev iek

Kaapse Skiereiland Elders

14. cpvoedinssviar.

Gecr: 5koolonleiding

Sub A-Std. ?

Std. 3

Sta. 4

std. 5

Std. 6

Sto. 7

Sta. 8

Sta. 9

Stc. 10

15. Vomge weriksontominzin (aantal jare gewerk) Geer

1 Maand-11 maande

i jaar-5 jaar 11 maande

6 Incr-9 jaar it maande 10 Jast
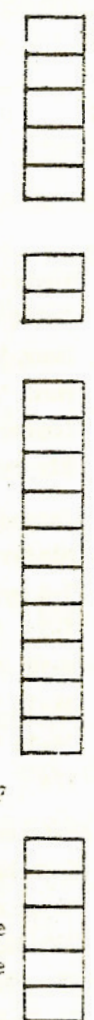

16. Torize ondervition in tie kiereneim:?

Geen.

; Maand-11 maande

Y Jaar-5 jaar 11 maence

e Jaar-9 jaar 11 maande

10 Jaar

23. bue het in die werk beicon.

Deur fanilic kontakte in die organisasie

Self diar gaan werk soei

of ' $n$ advertensie gereagee:
17. Aartal varige batrekkings (wrike) beikiee.

Geen

Een

Twee

Drie

Vier

Vyf of meet

18. Soort werk geioen vocy "dive orgenieasie"

Noen:

Bv. Huisvrou of huishediende of kefee- linkelbedience of klerefabriel:

19. Tydens apptikasie, was y!

Werkioos

of

In diens

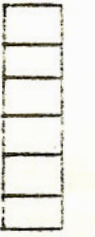

0. Periode werikinos Ninder as 6 maande

7 Maande -1 jaar

1 Jaar

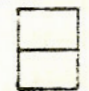

21. Famizie of vriende by "dive organisasie"

$\mathrm{Ja}$

Nee

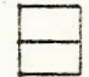

22. Vorige allaris per week

$R 3$ - R4.99

R5 - R6.9Q

$R 7$ - R8.99

Ro - R10.99

R1i - R12.99

R13 - R14.99

RIS - R16.99

$\mathrm{R} 17+$

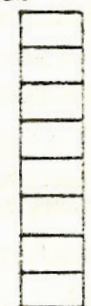

24. Eurituloning

Gereclu

Af en tor

Nooit 
Daar word dikwels gebruik gemaak van drie basiese klassifikasie-tipes om die gegewens in 'n meer bruikbare vorm aan te bied. Hierdie klassifikasie-metodes word ook deurgaans in hierdie studie gebruik. Die drie metodes kan soos volg opgesom word (England, 1961):

Die metode van gelyke frekwensieklasse. Die antwoorde van die gekombineerde eksperimentele groepe word in verskeie klasse, (4 tot 8) met naastenby 'n gelyke hoeveelheid indiwidue in elke klas, verdeel.

Die metode van gelyke intervalklasse. Die antwoorde op byvoorbeeld die ouderdomsitem word in intervalle van vyf jaar verdeel en die salarisitem in intervalle van $\mathrm{R} 2,00$.

Die metode van maksimum gewigsklasse. Hierdie metode berus basies op die probeer-en-tref-metode wat antwoordkategorieë of intervalgrense so bepaal dat dit die verskille tussen groepe op die beste manier sal beklemtoon.

\section{Insameling van gegewens}

Die lae kriteriumgroep wat getrek moes word uit die geledere van werknemers wat diens verlaat het binne ' $n$ periode van drie maande, is noodwendig persone wat nie meer by die organisasie in diens is nie. Soos verder in die studie blyk, skyn hierdie groep relatief meer onstabiel te wees as die gemiddelde individu en verander dikwels van woonplek binne 'n relatiewe kort tydsbestek. Om hierdie persone, wat by die monster betrek is, op te spoor, moes daar gebruik gemaak word van instansies en veldwerkers wat kennis van die tipe persone wat ondervra moes word, dra.

Die personeelbeamptes van die organisasie waar die studie uitgevoer is, was behulpsaam met die inwin van inligting en die voltooiing van vraelyste. Die Departement van Kleurlingsake het inligting aangaande die huidige adresse van diensverlaters verskaf. Sosiale werksters en geskoolde Kleurlingdames het in spesifieke geografiese gebiede vraelyste voltooi. Die ondersoeker het self baie werknemers besoek en/of telefonies met hul in aanraking gekom om inligting in te win. Van die 53 vraelyste wat gepos is aan werknemers wat nie persoonlik besoek kon word nie, is slegs $18 \%$ beantwoord. In die nagaan van die 
akkuraatheid waarmee die vraelyste voltooi is, is die meeste foute, gemaak ten opsigte van biografiese gegewens, ook gevind in vraelyste wat oor die pos ingevul is. Hierdie persone moes weer besoek word sodat persoonlike toesig oor die invul van die vraelyste gehou kon word.

\section{NAGAAN VAN DIE GELDIGHEID VAN DIE VOLTOOIDE VRAELYSTE}

'n Steekproef waarby 20 persone elk van die hoë en lae kriteriumgroepe ingesluit was, is uitgevoer om die korrektheid waarmee die vraelys voltooi is, te bepaal. Vir vergelykingsdoeleindes is veral gebruik gemaak van inligting in die organisasie se rekords.

Slegs $4 \%$ van die vraelyste het verskille getoon, maar in nie meer as twee items per persoon nie en die foutiewe gegewens was baie gering. Hierdie gevalle is reggestel, maar geen verdere opvolgstudie is gedoen nie, aangesien die afwyking as te gering beskou is.

Ten opsigte van een item naamlik, vorige salaris per week (no. 22 in die vraelys), is daar nie 'n voldoende bevredigende antwoord verkry nie. Sommige persone wou nie hierdie informasie verstrek nie. Die redes wat hiervoor aangevoer is, is baie uiteenlopend en persoonlik van aard. Daar is besluit om hierdie item geheel-en-al uit die verdere studie te laat.

Die enigste ander item wat nie bevredigend beantwoord is nie, is die item: hoeveelheid jare getroud (no. 4 in die vraelys). Item no. 3, huwelikstaat, sluit vanselfsprekend die ongetroude werknemers hier uit. Sulke items, sowel as item no. 5, naamlik getal afhanklikes, is in hulle wese kontingensie-items en moet dus met groter sorg in die ontleding behandel word as ander items. As die informasie wat van hierdie items verkry is, nie korrek verwerk word nie, kan die ontleding van kontingente items lei tot die toekenning van onverdiende hoë of lae gewigte aan die item. Die item, aantal afhanklikes, kan ook moontlik kontingent wees op die item, huwelikstaat. In hierdie geval is dit egter nie so behandel nie, omdat nie net kinders as afhanklikes beskou is nie, maar ook ouers, broers, susters, ensovoorts. Die groep werkers waarop hierdie studie gedoen is, se sosiale samestelling is ook heelwat verskillend van die (meer) bekende westerse mens s'n. So kom daar byvoorbeeld baie gevalle voor waar die werknemer ongetroud is, maar tog kinders het. 
Die roudata wat in die vraelys voorkom, moes opgesom en betekenisvol voorgestel word om verdere verwerking daarvan moontlik te maak. Die wyse waarop die roudata in tabelvorm opgesom is, word in Tabel 2 aangetoon.

TABEL 2

Voorbeeld van Opsomining van Roudata vanaf Vraelyste

\begin{tabular}{|c|c|c|}
\hline \multirow[b]{2}{*}{ Item } & \multicolumn{2}{|c|}{ Aantal } \\
\hline & $\begin{array}{c}\text { Groep I } \\
\text { Hoë Kriterium }\end{array}$ & $\begin{array}{l}\text { Groep II } \\
\text { Lae Kriterium }\end{array}$ \\
\hline \multicolumn{3}{|l|}{ Gestag } \\
\hline Manlik & 5 & 4 \\
\hline \multirow[t]{2}{*}{ Vroulik } & 45 & 46 \\
\hline & 50 & 50 \\
\hline \multicolumn{3}{|l|}{ ouderdor } \\
\hline $15-20$ & 21 & 31 \\
\hline $21-26$ & 11 & 7 \\
\hline $27-32$ & 6 & 3 \\
\hline $33-38$ & 8 & 4 \\
\hline $39-44$ & 3 & 4 \\
\hline $45-50$ & 1 & 1 \\
\hline \multirow[b]{2}{*}{ Totaal: } & 0 & 0 \\
\hline & 50 & 50 \\
\hline \multicolumn{3}{|l|}{ Graveilkstaat } \\
\hline Getroud & 22 & 15 \\
\hline Ongetroud & 25 & 33 \\
\hline Ceskiei & 0 & 1 \\
\hline Weduwee/wewenaar & 3 & 0 \\
\hline \multirow{2}{*}{$\begin{array}{c}\text { ongetroud met kinders } \\
\text { Totaal: }\end{array}$} & 0 & 1 \\
\hline & 50 & 50 \\
\hline \multicolumn{3}{|l|}{$\begin{array}{l}\text { Hoevee lheid jare ge- } \\
\text { troud }\end{array}$} \\
\hline Minder as 1 jaar & 2 & 1 \\
\hline $1-2$ jazr & 4 & 3 \\
\hline 3-5 jaar & 3 & 5 \\
\hline $6+$ jasr & 13 & 6 \\
\hline Totaal: & 22 & 15 \\
\hline \multicolumn{3}{|l|}{ Ens. } \\
\hline
\end{tabular}


Om die gewigte van verskillende items te bepaal, om sodoende vas te stel of gewensde werkers (in hoë kriteriumgroepe) anders reageer op sekere items as ongewensde werkers (in lae kriteriumgroepe), moet daar op 'n spesifieke tegniek of metode besluit word. 'n Werkskaart moet ontwikkel word om die bewerkings duidelik, doeltreffend en prakties deur te voer en voor te stel.

Die metode waarop in hierdie studie besluit is, berus op tabelle wat deur E.K. Strong Jnr. (Stead \& Shartlech, 1940); (Stone \& Kendall, 1958) (England, 1961) ontwikkel is van 'n formule wat daar gestel is deur T.L. Kelley (Stead \& Shartlech, 1940). Volledigheidshalwe en ter illustrasie word die tabel van Strong weergegee in Tabel 3.

Beide Welch (1961) en England (1961) is dit eens dat die tabelle van Strong baie geskik is vir die ontwikkeling van die G.A.V. deur gebruikmaking van biografiese gegewens, omdat die tabelle van Strong gebruik maak van verskille in die persentasie-reaksies van twee groepe wat met mekaar vergelyk word ten opsigte van een of ander faktor of eienskap om tot nettogewigte te kom.

Hierdie benadering tot die bepaling van item-gewigte staan as die "HorisontalePersentmetode" bekend. Die metode is bo ander meer gesofistikeerde en verfynde statistiese metodes vir die weging van die aansoekvorm verkies, omdat die horisontale-persentmetode baie eenvoudig is en omdat daar geen bewyse is dat die ingewikkelde metodes beter resultate na kruis-validasie lewer as die horisontale-persentbenadering nie (Guion, 1965,392). 
TABEL 3

Strong se Tabelle van Nettogewigte vir Verskille in Prestasie

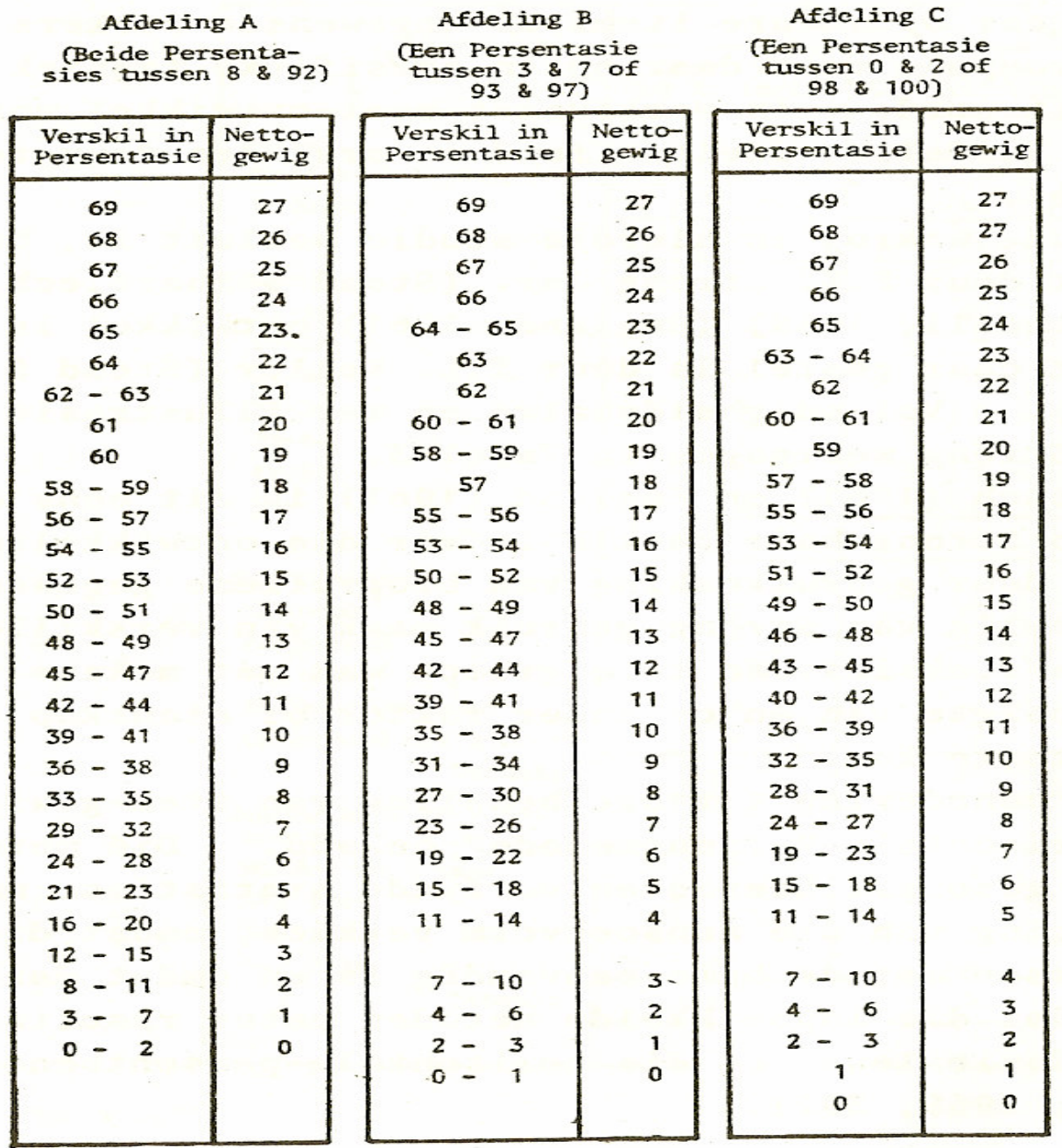

In Tabel 2 word 'n voorbeeld gegee van hoe die roudata van die vraelyste opgesom is. Hierdie gegewens moet nou na persentasies oorgeskakel word, daar die tabelle van Strong gebruik maak van die verskille in die persentasies vir afsonderlike kategorieë van antwoorde op items.

Om die nettogewigte volgens Strong as tabelle te bereken, word soos volg te werk gegaan: As die persentasies vir 'n gegewe antwoordkategorie tussen $8 \%$ en $92 \%$ geleë is, word afdeling A gebruik om die nettogewig te bepaal op grond van die verskil tussen die twee persentasies wat toegeken is aan die hoë en lae kriteriumgroepe. As een of beide persentasies tussen $3 \%$ en $7 \%$ of tussen $93 \%$ en $97 \%$ is, word van afdeling B gebruik gemaak om die nettogewigte af te lees. As een of beide persentasies tussen $0 \%$ en $2 \%$ of tussen $98 \%$ en $100 \%$ lê, word gebruik gemaak van afdeling C van Strong se tabelle. 
Om die verskil in persentasies te verkry, word die persentasie wat deur die lae kriteriumgroep behaal is, altyd afgetrek van die persentasie wat deur die hoë kriteriumgroep behaal is. Afhangende van die grootte van die oorspronklike persentasies, word daar gebruik gemaak van die tabel van Strong wat van toepassing is om die nettogewig af te lees.

Inderwaarheid kan die berekening van gewigte reeds hier eindig. Die nettogewigte is egter baie groot en lomp om mee te werk. Die feit dat daar positiewe en negatiewe nettogewigte verkry kan word, bemoeilik ook die gebruik van die G.A.V. in die praktyk. Om bogenoemde probleme die hoof te bied het England (Mood \& Graybill, 1966) 'n metode ontwikkel waarin daar van die gegewens in Tabel 4 gebruik gemaak word. Hierdie tabel bied kleiner positiewe getalle aan wat van die nettogewigte wat verkry is van Strong se tabelle, afgelees kan word. Die toegekende gewigte sal numeriese opsomming van die aansoekvorm in die praktyk baie vereenvoudig en bespoedig. Met die voordele wat verkry is deur England se tabel te gebruik, kan daar egter ook nadele wees soos byvoorbeeld die kleiner onderskeidingsveld wat verkry word deur slegs die drie toegekende gewigte te gebruik.

\section{TABEL 4}

ENGLAND SE TABEL VAN TOEGEKENDE GEWIGTE AFGELEI VAN NETTOGEWIGTE

\begin{tabular}{|l|c|}
\hline \multicolumn{1}{|c|}{ Nettogewig } & Toegekende Gewig \\
\hline-4 of minder & 0 \\
$3,2,1,0,-1,-2,-3$ & 1 \\
4 of meer & 2 \\
\hline
\end{tabular}

Dit is belangrik om daarop te let dat enige item wat dieselfde toegekende gewigte behaal vir al sy antwoordkategorieë, nie differensieer of nie voldoende differensieer tussen die hoë en lae kriteriumgroepe in die eksperimentele stadium nie. Sulke items moet dus weggelaat word uit die aansoekvorm, aangesien dit nie bydra tot die finale doel, naamlik seleksie, nie.

Daar Tabel 4 duidelik bloot 'n arbitrêre afleiding van klassifikasies aan die kant van England is, is dit statisties nie foutief (Yoder, 1958) om enige ander aanvaarbare klassifikasie te maak om die navorser se behoeftes beter te bevredig nie. Daarom is daar ' $n$ ander alternatiewe moontlike klassifikasie vir die weergawe van resultate oorweeg en dit word in Tabel 5 weergegee.

Uit Tabel 5 is dit duidelik dat met hierdie klassifikasie van nettogewigte 'n wyer verspreiding verkry word wat baie fyner en noukeuriger differensieer. 


\section{TABEL 5}

\section{ALTERNATIEWE KLASSIFIKASIE VAN TABEL VAN TOEGEKENDE GEWIGTE AFGELEI VAN NETTOGEWIGTE}

\begin{tabular}{|l|c|}
\hline \multicolumn{1}{|c|}{ Nettogewig } & Toegekende Gewig \\
\hline-4 of minder & 0 \\
$-2,-3$ & 1 \\
$-1,0,1$ & 2 \\
$+2,+3$ & 3 \\
+4 of meer & 4 \\
\hline
\end{tabular}

Dit is egter in eksperimente gevind dat dit eerder die gewigte "opblaas" as wat dit enige verdere bydrae lewer bo en behalwe die kwaliteit wat omsluit is in Tabel 4. So het Mc Grath (1960-61) toe hy dieselfde probleem ondervind het, besluit om slegs van drie gewigsmoontlikhede, te wete 0,1 , en 2 gebruik te maak omdat dit relatief meer voordele bied as die wyer verspreidings.

Die vyf gewigsverspreidings soos in Tabel 5 aangetoon, was egter in hierdie studie van groot nut. Dit openbaar die besondere eienskap om item-klassifikasies aan te dui wat saam gekombineer moet word om goeie resultate te verkry. 'n Voorbeeld hiervan volg later in die studie (Tabel 7 op bladsy 21).

\section{Keuse van alternatiewes}

In sommige studies op die gebied van die G.A. V. waarin van Strong se tabelle gebruik gemaak is, is elke item wat enigsins 'n verskil in enige antwoordkategorie toon, sonder verdere oorwegings netso in die aansoekvorm opgeneem. Alhoewel dit aanvaar kan word dat alle verskille wat deur die toegekende gewigte aangetoon word in die studie opgeneem kan word, is daar in verskeie studies 'n stappie verder gegaan soos ook deur England in sy boek aanbeveel word. In hierdie studie is alle moontlike kombinasies van elke item se antwoordkategorie uitprobeer om sodoende te kom tot itemklassifikasies wat die verskille tussen die kriteriumgroepe die beste sal beklemtoon.

'n Sespunt-indikatorstelsel (sleutels) is ontwikkel om te bepaal watter alternatiewe itemkombinasies gekies moet word om in die G.A.V. opgeneem te word. 


\section{Die ses sleutels}

Die ses sleutels is die volgende: (a) Kies eerder daardie alternatiewe met die grootste verskil in toegekende gewigte. (b) Kies eerder daardie alternatiewe met die grootste verskil in nettogewigte. (c) Kies eerder daardie alternatiewe met die grootste aantal persone in alle antwoordkategorieë. (d) Kies eerder daardie alternatiewe wat die grootste praktiese waarde vir seleksie inhou. (e) Kies eerder daardie alternatiewe met die grootste beduidende verband tussen biografiese faktore en die kriterium. (f) Kies die alternatiewe deur 'n kompromie aan te gaan tussen bogenoemde rigtingwysers.

Die volgorde waarin die ses sleutels hierbo genoem is, kom naastenby ooreen met die mate waarin elkeen belangrik is vir die keuring van alternatiewe.

\section{BEPALING VAN ITEMGEWIGTE VERWERKING VAN GEGEWENS}

Om te kom tot die gewigte soos onder die opskrif "Bepaling van itemgewigte" uiteengesit, is van 'n werksvorm gebruik gemaak wat die werkskaart wat in Tabel 2 aangetoon is, aanvul om 'n geïntegreerde werkskaart te verskaf.

Tabel 6 is 'n voorbeeld van so 'n geïntegreerde werkskaart en gee die bewerking van die eerste biografiese item, geslag, weer wat in die vraelys (Tabel 1) genoem word. Die eerste tabel van elke nuwe biografiese item bevat die data soos dit verkry is, van die oorspronklike vraelysopsomming. Hierdie klassifikasie is altyd wyd en soveel klasse as wat prakties moontlik is, word gebruik om so min gegewens as moontlik verlore te laat gaan en om voldoende ruimte te laat vir die latere herkombinasie van itemklasse.

'n Paar items sal voorts in tabelvorm behandel word ter illustrasie van die prosedure wat gevolg is. Die ander items wat beduidend onderskei tussen hoë en lae kriteriumgroepe, sal daarna opsommend volgens die klassifikasie wat verkies is, weergegee word.

Voordat die tabelle verder ontleed word, moet die interpretasie wat aan die toegekende gewigte geheg word, kortliks bespreek word.

Itemklasse wat 'n gewig (toegeken) van twee behaal, dui op die hoogs gewensde groep werknemers ten opsigte van die besondere item. Daarenteen toon itemklasse waaraan 'n nul toegeken is, die mees ongewensde groep werknemers onder 'n spesifieke item aan. 'n Toegekende gewig van een beteken dat daar geen onderskeiding tussen gewensde en 
ongewensde werknemers ten opsigte van daardie itemklas gevind is nie. Daar kom byna net soveel gevalle van die hoë as van die lae kriteriumgroep in die itemklas voor.

TABEL 6

Biografiese Item: Geslag

\begin{tabular}{|c|c|c|c|c|c|c|c|}
\hline \multirow{2}{*}{ Item Kolom } & \multicolumn{2}{|c|}{ Aantal } & \multicolumn{2}{c|}{ Persentasie } & Kol. 4 \\
\cline { 2 - 7 } & $\begin{array}{c}\text { Gr. I } \\
\text { Hoog }\end{array}$ & $\begin{array}{c}\text { Gr. II } \\
\text { Laag }\end{array}$ & $\begin{array}{c}\text { Gr. I } \\
\text { Hoog }\end{array}$ & $\begin{array}{c}\text { Gr. II } \\
\text { Laag }\end{array}$ & $\begin{array}{c}\text { Netto } \\
\text { Kewig }\end{array}$ & $\begin{array}{c}\text { Toege- } \\
\text { kende } \\
\text { Gewig }\end{array}$ \\
\hline Geslag & & & & & & & \\
Manlik & 5 & 4 & 10 & 8 & +2 & 0 & 1 \\
Vroulik & 45 & 46 & 90 & 92 & -2 & 0 & 1 \\
\hline Totaal & 50 & 50 & $100 \%$ & $100 \%$ & & & \\
\hline
\end{tabular}

$*_{G}=0,12(G . V .=1) \quad 10 \%$-peil $=2,7055 \quad r_{\phi}=0,035$

Soos aangetoon in die laaste kolom van Tabel 6 (toegekende gewigte) is beide die gewigte van dieselfde numeriese waarde. Geslag onderskei dus nie tussen gewensde en ongewensde werknemers nie. Hier is geen praktiese herkombinasie nodig of moontlik nie. Geen verdere aandag hoef dus meer aan hierdie item geskenk te word nie. Reeds die eerste sleutel dui hier voldoende aan dat die item nie in die G.A.V. opgeneem kan word nie.

Vervolgens word die biografiese item, ouderdom in Tabel 7 behandel:

TABEL 7

Biografiese Item: Ouderdom

\begin{tabular}{|c|c|c|c|c|c|c|c|c|}
\hline \multirow{2}{*}{ Kolom } & \multicolumn{2}{|c|}{ Aantal } & \multicolumn{2}{|c|}{ Persentasie } & \multirow{2}{*}{$\begin{array}{c}\text { Kol. } 4 \\
\text { min } \\
\text { Kol. } 5\end{array}$} & \multirow{2}{*}{$\begin{array}{l}\text { Netto } \\
\text { Gewig }\end{array}$} & \multirow{2}{*}{\multicolumn{2}{|c|}{$\begin{array}{l}\text { Toegeken- } \\
\text { de Gewig }\end{array}$}} \\
\hline & Gr. I & Gr. II & Gr. I & Gr. II & & & & \\
\hline Ouderdom & & & & & & & & 5. kras \\
\hline 15-20 jaar & 21 & 31 & 42 & 62 & -20 & -4 & 0 & $\begin{array}{ll}0 & 1 \\
\end{array}$ \\
\hline $21-26 \quad "$ & 11 & 7 & 22 & 14 & 8 & 2 & 1 & 3 \\
\hline $27-32 \quad "$ & 6 & 3 & 12 & 6 & 6 & 2 & 1 & 3 \\
\hline $33-38 "$ & 8 & 4 & 16 & 8 & 8 & 2 & 1 & 3 \\
\hline $39-44 \quad "$ & 3 & 4 & 6 & 8 & -2 & -1 & 1 & 2 \\
\hline $45-50 \quad "$ & 1 & 1 & 2 & 2 & 0 & 0 & 1 & 2 \\
\hline $51+\quad "$ & 0 & 0 & 0 & 0 & 0 & 0 & 1 & 2 \\
\hline Totaal & 50 & 50 & $100 \%$ & $100 \%$ & & & & \\
\hline
\end{tabular}

\footnotetext{
* Vir die berekening van die G-waarde kan van 'n matrys, soos deur Woolf (1965) voorgestel, gebruik gemaak word. Die berekening van G word egter baie vergemaklik deur gebruik te maak van Wilks \& Fisher (1965-67) se afgeleide logaritmetafels.
} 
Uit Tabel 7 blyk dit dat 'n aspirant werknemer tussen die ouderdom 15 en 20 jaar nie 'n baie goeie keuse is om in diens geneem te word nie, aangesien die groep die laagste gewig van "0" behaal het. Die tabel differensieer nie tussen ouderdomsgroepe groter as 21 jaar nie. Dit sal dus op grond van hierdie data alleen gewens wees om werknemers wat ouer as 21 jaar is, in diens te neem. Die tabel onderskei slegs tussen die twee groepe naamlik jonger as 20 jaar en ouer as 21 jaar. Die resultate is wel bruikbaar deurdat daar wel 'n onderskeid tussen die hoë en lae kriteriumgroepe gevind is, maar die onderskeid is baie vaag en lomp.

Soos reeds voorheen genoem, openbaar die vyf-klas-verspreiding wat in Tabel 5 aangetoon is, die besondere eienskap dat dit aandui watter itemklasse saamgegroepeer kan word.

In die laaste kolom van Tabel 7 is die vyf-klas-verspreiding van toegekende gewigte (in hakies) langs die drie-klasverspreiding van toegekende gewigte wat oorspronklik in Tabel 4 aangegee is, geplaas. Hierdie is 'n goeie voorbeeld van hoe die vyf-klas-verspreiding (Tabel 5) die beste kombinasie afbaken. Dit is die drie klasse wat deur die verbindingshakies ingesluit word.

Tabel 8 gee die alternatiewe verspreiding weer.

Die toegekende gewigte in die laaste kolom van Tabel 8 onderskei in hierdie geval baie sterk. Hierdie kombinasie en verkreë onderskeiding tussen die ouderdomsgroepe is rasioneel en goed te regverdig en wel op die volgende wyse:

Die werknemers tussen die ouderdomme 15 en 20 jaar is nog in hulle jeugjare en is minder verantwoordelik as die werknemers tussen die ouderdomme 21 en 28 jaar. Die werknemers in die middelste ouderdomsgroep is diegene met afhanklikes en hulle openbaar reeds aansienlik meer verantwoordelikheid as eersgenoemde groep. Die werknemers van 39 en ouer is moontlik meer onderhewig aan swak gesondheid ensovoorts, wat kan veroorsaak dat hulle die werk moet verlaat, maar selfs dié groep is meer gewens as die jong groep. 
TABEL 8

Ouderdom - (Verwerking)

\begin{tabular}{|c|c|c|c|c|c|c|c|}
\hline \multirow{2}{*}{ Item Kolom } & \multicolumn{2}{|c|}{ Aantal } & \multicolumn{2}{|c|}{ Persentasie } & \multirow{2}{*}{$\frac{\text { Kol. } 4}{\min }$} & \multirow{2}{*}{$\begin{array}{l}\text { Netto } \\
\text { Gewig }\end{array}$} & \multirow{2}{*}{$\begin{array}{l}\text { Toege- } \\
\text { kende } \\
\text { Gewig }\end{array}$} \\
\hline & $\begin{array}{l}\text { Gr. I } \\
\text { Laag }\end{array}$ & $\begin{array}{c}\text { Gr.II } \\
\text { Hoog }\end{array}$ & $\begin{array}{l}\text { Cr. I } \\
\text { Laag }\end{array}$ & $\begin{array}{l}\text { Gr.II } \\
\text { Hoog }\end{array}$ & & & \\
\hline ouderdom & & & & & & & \\
\hline $15-20$ jaar & 21 & 31 & 42 & 62 & -20 & -4 & 0 \\
\hline 21-38 jaar & 25 & 14 & 50 & 28 & +22 & 5 & 2 \\
\hline $39-50$ jaar & 4 & 5 & 8 & 10 & 2 & 0 & 1 \\
\hline Totaal & 50 & 50 & $100 \%$ & $100 \%$ & & & \\
\hline
\end{tabular}

$\mathrm{G}=5,18\left(\mathrm{G}_{0} \mathrm{~V}_{0}=2\right) \quad 10 \%$-peil $=4,6052$

Beduidend op $10 \%$-peil $\quad 5 \%$-peil $=9,2103$

Die kombinasie is, soos dit uit die bostaande bespreking blyk, vir praktiese seleksiedoeleindes van groot waarde en die verskil in gewigte is baie duidelik. Dit is dus nie nodig om enige van die ander vyf sleutels aan te wend nie.

Geen alternatiewe klassifikasies kon beter resultate in terme van die ses sleutels lewer nie. Om hierdie rede is die syfer-klas-verspreiding van Tabel 5 deurgaans in die studie gebruik as rigtingwyser om goeie kombinasies te kry wanneer nodig.

Ouderdom, en wel die alternatief in Tabel 8, is dus die eerste item wat in die G.A.V. opgeneem kan word.

Weens 'n gebrek aan ruimte sal die ander items nie afsonderlik behandel word nie. In die besondere studie waarop hierdie illustrasie van die ontwikkeling van 'n G.A.V. gebaseer is, is daar egter baie aandag aan die interpretasie van watter betekenis aan itemresultate vir die besondere werkersgroep (die Wes-Kaapse Kleurling) geheg kan/moet word, gewy.

\section{Samevatting van items en gewigte}

Daar is dertien items uit 'n moontlike totaal van 23 gevind wat genoegsaam onderskei tussen die hoë en lae kriteriumgroepe om in die G.A.V. opgeneem te word. Dit is heelwat hoër as wat in ander soortgelyke studies gevind is (Scott en Johnson, 1967). In Tabel 9 word die suksesvolle biografiese faktore, die klassifikasies en die toegekende gewigte aangetoon. 
Daar bestaan baie bewyse wat daarop dui dat dit baie misleidend kan wees om 'n stel empiriese gewigte te ontwikkel wat tussen twee groepe differensieer en die gewigte dan op dieselfde groepe te evalueer (Mosier, C.I. et.al., 1951 en Guion, 1965, p.394). 'n Ontleding van die G.A.V. kan beswaarlik as wetenskaplik geldig beskou word as daar nie voorsiening gemaak word vir afsonderlike monsters om die resultate (gewigte) na te gaan en te evalueer nie. Om hierdie rede kan die gebruik van validasiegroepe as 'n absolute noodsaaklikheid en 'n integrale deel van die totale proses beskou word.

Noudat toegekende gewigte bepaal is soos op bladsye 23 en 24 geïllustreer, moet aan elke individu in die hoë en lae validasiegroepe gewigte toegeken word in ooreenstemming met hulle reaksies op items wat voldoende differensieer tussen die twee eksperimentele groepe.

In Tabelle 10 en 11 (slegs 'n uittreksel van elk word as voorbeeld weergegee), is die korresponderende gewigte (volgens die verskillende klasse onder elke item) en die totale gewigte respektiewelik vir die hoë en lae validasiegroepe bepaal. Aan elke individu, wat voorgestel word deur die numeriese waardes aan die linkerkant van die bladsy, word die itemgewigte toegeken volgens die klasse waarin hy/sy ressorteer .. Die totale gewig wat vir elke individu bereken word in die G.A.V., is dan die som van die toegekende gewigte vir die persoon se antwoorde ten opsigte van die onderskeidende items wat in die G.A.V. opgeneem is. Die totale gewig vir elke individuele persoon verskyn in die laaste kolomme van Tabelle 10 en 11.

Die groot verskil tussen die hoë en die lae validasiegroepe ten opsigte van die totale gewigte is duidelik uit Tabelle 10 en 11, respektiewelik. Hierdie waardes wissel van 20 in Tabel 10 tot 6 in Tabel 11. 
TABEL 9

Samevatting van Items en Gewigte wat Suksesvol Differensieer tussen Hoë en Lae Kriteriumgroepe

\begin{tabular}{|c|c|c|}
\hline & $\begin{array}{c}\text { Biografiese Faktore en } \\
\text { Klassifikasic }\end{array}$ & $\begin{array}{l}\text { Toegekende } \\
\text { gewigte }\end{array}$ \\
\hline 1. & $\begin{array}{l}\text { Ouderdon } \\
15-20 \text { Jaar } \\
21-38 \quad " \\
39-50 \quad "\end{array}$ & $\begin{array}{l}0 \\
2 \\
1\end{array}$ \\
\hline 2. & $\begin{array}{l}\text { Havelikataat } \\
\text { Getroud } \\
\text { Ongetroud } \\
\text { Anutersins (getroud met kin- } \\
\text { ders, gesikei, weulwee/we- } \\
\text { wenaar) }\end{array}$ & $\begin{array}{l}1 \\
0 \\
1\end{array}$ \\
\hline 3. & $\begin{array}{l}\text { Aantal jore getroud } \\
2 \text { Jaar en minder } \\
3-5 \text { Jaar } \\
6+\quad "\end{array}$ & $\begin{array}{l}1 \\
0 \\
2\end{array}$ \\
\hline 4. & $\begin{array}{l}\text { Gesoniheid } \\
\text { Redelik tot goed } \\
\text { Swak }\end{array}$ & $\begin{array}{l}1 \\
0\end{array}$ \\
\hline 5. & $\begin{array}{l}\text { Afotond var werk } \\
\text { Minder as } 1 \text { my } 1 \\
1-13 \text { my } 1 \\
14+\quad \text {. }\end{array}$ & $\begin{array}{l}2 \\
0 \\
2\end{array}$ \\
\hline ó. & $\begin{array}{l}\text { Etriese groepe } \\
\text { Kleurling } \\
\text { Maleier }\end{array}$ & $\begin{array}{l}0 \\
2\end{array}$ \\
\hline 7. & $\begin{array}{l}\text { Aantal broabinners } \\
\text { Een } \\
\text { Twee } \\
\text { Drie } \\
\text { Vier } \\
\text { Yyt on meer }\end{array}$ & $\begin{array}{l}1 \\
1 \\
1 \\
2 \\
1\end{array}$ \\
\hline
\end{tabular}


TABEL 9 (VERVOLG)

\begin{tabular}{|c|c|c|}
\hline & $\begin{array}{c}\text { Biografiest Faktore en } \\
\text { Kiassifikasie }\end{array}$ & $\begin{array}{c}\text { Toegeiverdk } \\
\text { geniset }\end{array}$ \\
\hline 8. & $\begin{array}{l}\text { Opvoedingspeit } \\
\text { Sut A - Std. } 2 \\
\text { Sta. } 3 \\
\text { Std. } 4 \\
\text { Std. } 5 \\
\text { Std. } 6 \\
\text { Std. } 7 \\
\text { Std. } 8\end{array}$ & $\begin{array}{l}1 \\
0 \\
1 \\
1 \\
2 \\
i \\
1\end{array}$ \\
\hline 9. & $\begin{array}{l}\text { Vorigc werkoncieminaing } \\
11 \text { Maande en minder } \\
1 \text { Jaar - } 9 \text { jăr } 11 \text { maande } \\
10 \text { Jaar* }\end{array}$ & $\begin{array}{l}0 \\
1 \\
2\end{array}$ \\
\hline 10. & $\begin{array}{l}\text { Vorige ondervinding in dìe } \\
\text { kierasiebedinf } \\
\text { Gcen } \\
1 \text { Maand - } 11 \text { iacande } \\
1 \text { Jaar - } 9 \text { jaar } 11 \text { maande } \\
10 \text { Jaart }\end{array}$ & $\begin{array}{l}1 \\
1\end{array}$ \\
\hline 11. & $\begin{array}{l}\text { Werkioosin diens tydens aan- } \\
\text { snek } \\
\text { Werkloos } \\
\text { In diens }\end{array}$ & $\begin{array}{l}1 \\
2\end{array}$ \\
\hline 12. & $\begin{array}{l}\text { Periode werkioos } \\
\text { Minder as } 6 \text { maande } \\
7 \text { Mande - } 1 \text { jaar } \\
1 \text { jaart }\end{array}$ & $\begin{array}{l}i \\
0 \\
2\end{array}$ \\
\hline 13. & $\begin{array}{l}\text { Hoe is wisk bekom } \\
\text { Familie in organisasie } \\
\text { Self gaan werk soek }\end{array}$ & 2 \\
\hline
\end{tabular}


VERSPREIDING VAN TOTALE GEWIGTE EN BEPALING VAN DIE

AFSNYGEWIG VIR SELEKSIE

Om 'n geheelbeeld te verkry van hoe goed die gekose geweegde items daarin slaag om tussen gewensde en ongewensde werkers te onderskei, word 'n grafiese verspreiding van die totale gewigte vir elke validasiegroep in Figuur 4 weergegee. Deur die basislyn van die grafieke regoor mekaar te trek, is 'n vergelyking van die hoë en lae kriteriumgroepe se totale gewigsverspreiding met 'n oogopslag moontlik. Elke punt verteenwoordig een persoon en sy posisie langs die horisontale skaal dui sy/haar totale gewig op die G.A.V. aan.

TABEL 10

Validasiegroep van Hoë Kriteriumgroep

Biografiese Faktore

\begin{tabular}{|c|c|c|c|c|c|c|c|c|c|c|c|c|c|c|}
\hline . & Oucle rómil & $\begin{array}{c}\text { Invelik- } \\
\text { start }\end{array}$ & $\begin{array}{c}\text { Aintal } \\
\text { jaye } \\
\text { getrinul }\end{array}$ & $\begin{array}{l}\text { (iesond- } \\
\text { heid }\end{array}$ & $\begin{array}{c}\text { Afctand } \\
\text { van } \\
\text { werk }\end{array}$ & $\begin{array}{c}\text { Etuniese } \\
\text { groen }\end{array}$ & $\begin{array}{l}\text { Aontal } \\
\text { brood- } \\
\text { winners }\end{array}$ & $\begin{array}{l}\text { Opvoe- } \\
\text { plings- } \\
\text { peil }\end{array}$ & $\begin{array}{l}\text { Vorige } \\
\text { werks- } \\
\text { ontler- } \\
\text { vinding }\end{array}$ & $\begin{array}{l}\text { Vorige } \\
\text { onder- } \\
\text { vinding } \\
\text { in klere- } \\
\text { bedryf }\end{array}$ & $\begin{array}{l}\text { Werk- } \\
\text { lons } \\
\text { tydens } \\
\text { appli- } \\
\text { kasie }\end{array}$ & $\begin{array}{c}\text { Periode } \\
\text { werk- } \\
\text { loos }\end{array}$ & $\begin{array}{l}\text { lke } \\
\text { werk } \\
\text { bekonn }\end{array}$ & Totaal \\
\hline 1. & 0 & 0 & 1 & 1 & 2 & 2 & 2 & 1 & 1 & 1 & $z$ & 1 & 0 & 14 \\
\hline 2. & 2 & 1 & 2 & 0 & 2 & 0 & 1 & 2 & 2 & $i$ & 1 & 1 & n & 15 \\
\hline 3. & 2 & 1 & 2 & 1 & 0 & 0 & 1 & 1 & 1 & 1 & 1 & 2 & 0 & 13 \\
\hline 4. & 0 & 0 & 1 & 1 & 2 & 0 & 1 & 1 & 1 & 1 & 1 & 1 & 0 & 11) \\
\hline 5. & 2 & 0 & 1 & 1 & 2 & 2 & 1 & 1 & 0 & 1 & 1 & 2 & 2. & 16 \\
\hline 6. & 1 & 1 & 2 & 1 & 2 & 0 & 1 & 1 & 2 & 1 & 2 & 1 & 2 & 17 \\
\hline 7. & 2 & 1 & 2 & 1 & 2 & 0 & 1 & 2 & 1 & 1 & 1 & 2 & 2 & 18 \\
\hline 8. & 2 & D & 1 & 1 & 2 & 2 & 2 & 2 & 1 & 1 & 2 & 1 & 2 & \\
\hline
\end{tabular}

Validasiegroep van Lac Kriteriımgroep

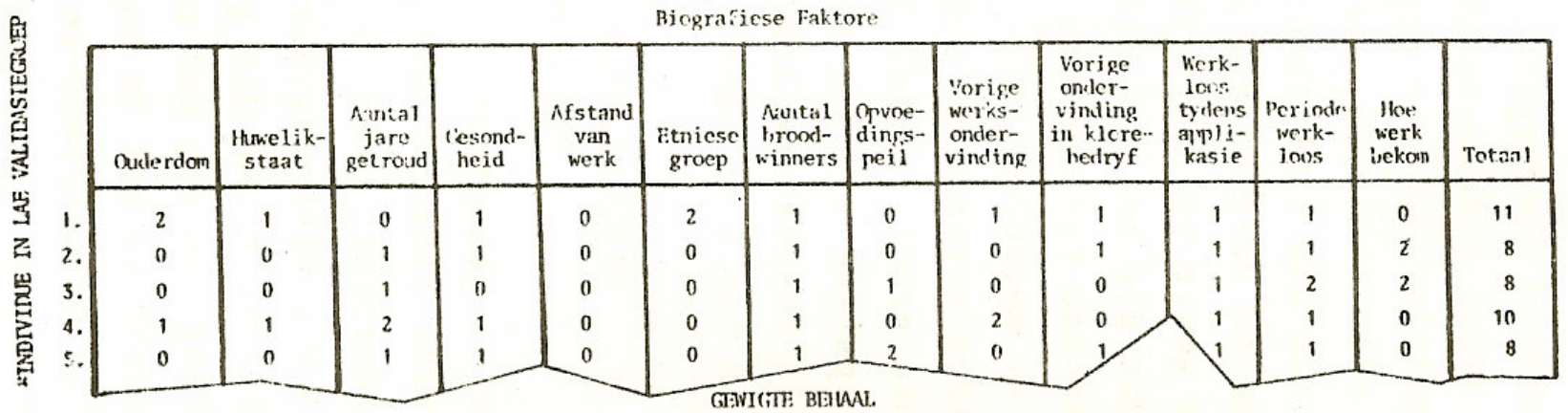




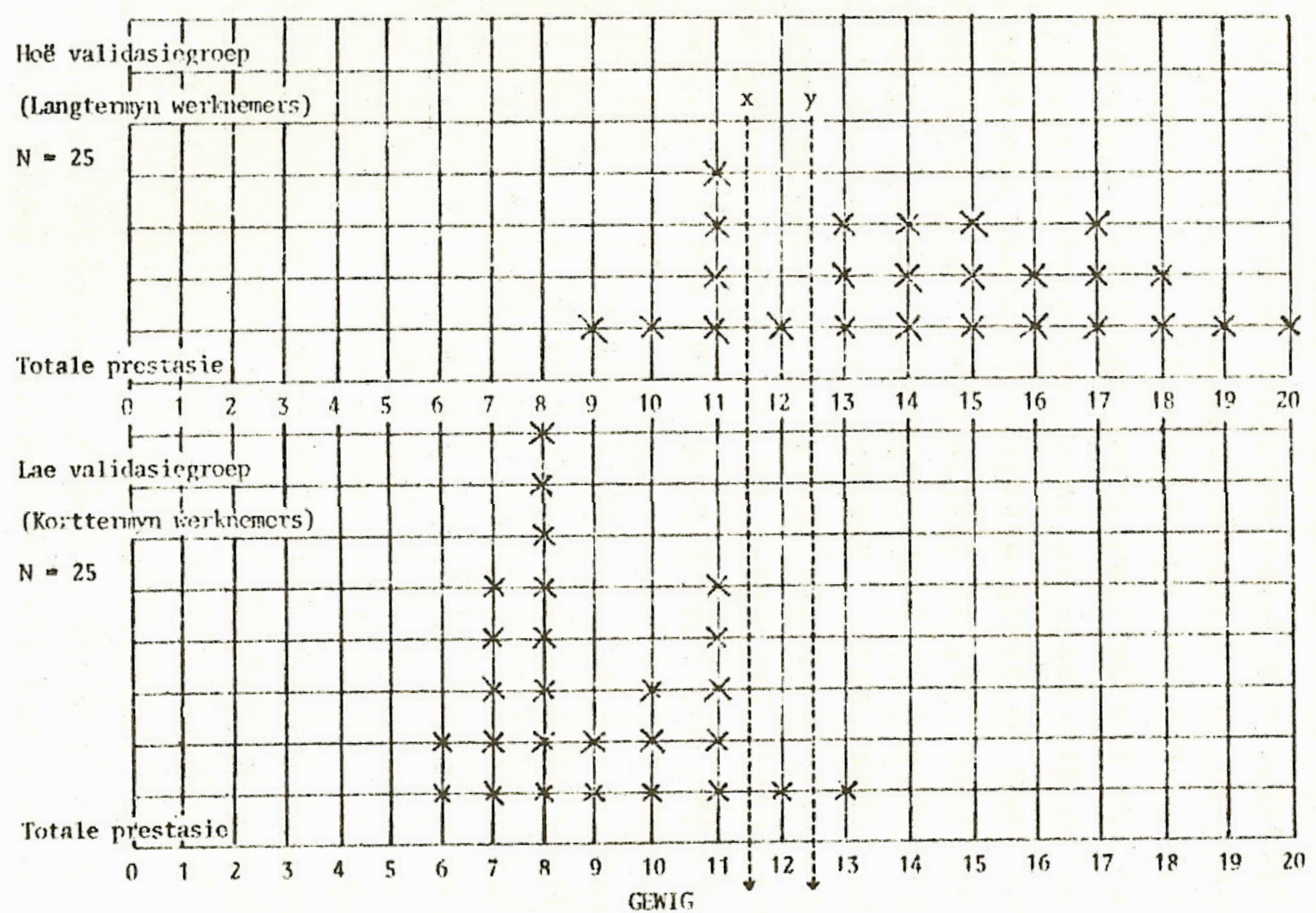

Figuur 4. Verspreiding van totale gewigte.

Die vergelyking tussen die twee verspreidings toon dat die langtermynwerknemers as 'n groep 'n baie hoër totale telling vir die aansoekvormitems behaal het as die korttermynwerknemers. Volgens Figuur 4 is daar 'n opeenhoping van tellings aan die bo-end van die skaal (tussen 9 en 20) vir die langtermyngroep, terwyl die oorgrote meerderheid van die korttermynwerknemers aan die onderend van die skaal geleë is tussen 6 en 13). Dit dui dus daarop dat die aanwending van die gewigte wat vir die dertien items ontwikkel is, suksesvol onderskei tussen die lang- en korttermynwerknemers.

Alhoewel daar 'n skerp onderskeid tussen die twee groepe in die grafiek verkry is, is daar nogtans 'n mate van oorvleueling. Daar is byvoorbeeld 'n korttermynwerknemer wat ' $n$ totale gewig van dertien behaal het. Daarteenoor is daar ook 'n langtermynwerknemer met ' $n$ totale gewig van so laag as nege.

'n Oorvleueling kan egter in die praktyk verwag word. Dit is nie te sê dat die studie en dus ook die G.A.V. wat daaruit voortvloei, van minder waarde is nie. Die vraag is eerder 
hoeveel maal groter die waarskynlikheid is om 'n gewensde werknemer in diens te neem met behulp van 'n G.A.V. as daarsonder. Dit gaan dus hier nie om individuele gevalle waar 'n ongewensde werknemer moontlik in diens geneem kan word of 'n gewensde werknemer verlore gaan nie. Die situasie moet in sy geheel gesien word.

Daar kan wel $40 \%$ tot $48 \%$ oorvleueling voorkom en daar bestaan 'n moontlikheid dat ongewensde werkers met behulp van die G.A.V. by seleksie ingesluit gaan word, maar dan kan die organisasie nog sekerheid hê dat $52 \%$ tot $60 \%$ van die werknemers wat wel so in diens geneem is, gewensde werkers is. Hierdie sekerheid sou die organisasie nie gehad het sonder die hulp van die G.A.V. nie.

Die organisasie kan ook vooraf bepaal hoe die G.A.V. aangewend gaan word in terme van groter sekerheid of risiko deur bloot die afsnypunt vir indiensname te verskuif. As die afsnypunt volgens Figuur 4 'n gewig van 14 is, sal net gewensde werkers in diens geneem word (60\% van die gewensde groep), maar daar sal ook meer gewensde werkers verloor word as in gedagte gehou word dat een gewensde werker in die hoë validasiegroep 'n totale gewig van nege behaal het. Deur die afsnypunt egter weer so laag as op nege te stel, gaan daar 'n groot groep ongewensde werknemers in diens geneem word.

Deur die afsnypunt te verskuif, word die daling of styging van die waarskynlikheid om gewensde of ongewensde werknemers in diens te neem, dus geaffekteer. Die vasstelling van die afsnypunt of prestasie waarbo applikante in diens geneem en waaronder hulle van die hand gewys word, is dus 'n baie belangrike aspek by die ontwikkeling van 'n G.A.V.

\section{Objektiewe bepaling van afsnypunt}

Om die afsnypunt te bepaal, word daar gebruik gemaak van 'n meer objektiewe metode as die blote inspeksie van die verspreiding. Die metode van maksimum differensiasie tussen validasiegroepe is hier aangewend soos dit in Tabel 12 weergegee is. Die persentasies van elke validasiegroep wat gewigte behaal op of bo elke moontlike totale gewig op die G.A.V. word bereken. Die indeks van differensiasies vir elke moontlike gewig word verkry deur die persentasies van groep II (korttermynwerknemers) af te trek van die persentasies van groep I (langtermynwerknemers). Die gewig waarby die indeks van differensiasie die grootste is, is die beste afsnypunt.

Vir die berekening van Tabel 12 is daar gebruik gemaak van die data in Figuur 4. Die grootste indeks van differensiasie in Tabel 12 is 68 . In hierdie studie is dit egter die geval dat 
daar twee maksimum differensiasiepunte is. Beide 12 en 13 kan volgens hierdie metode gekies word as afsnypunte.

TABEL 12

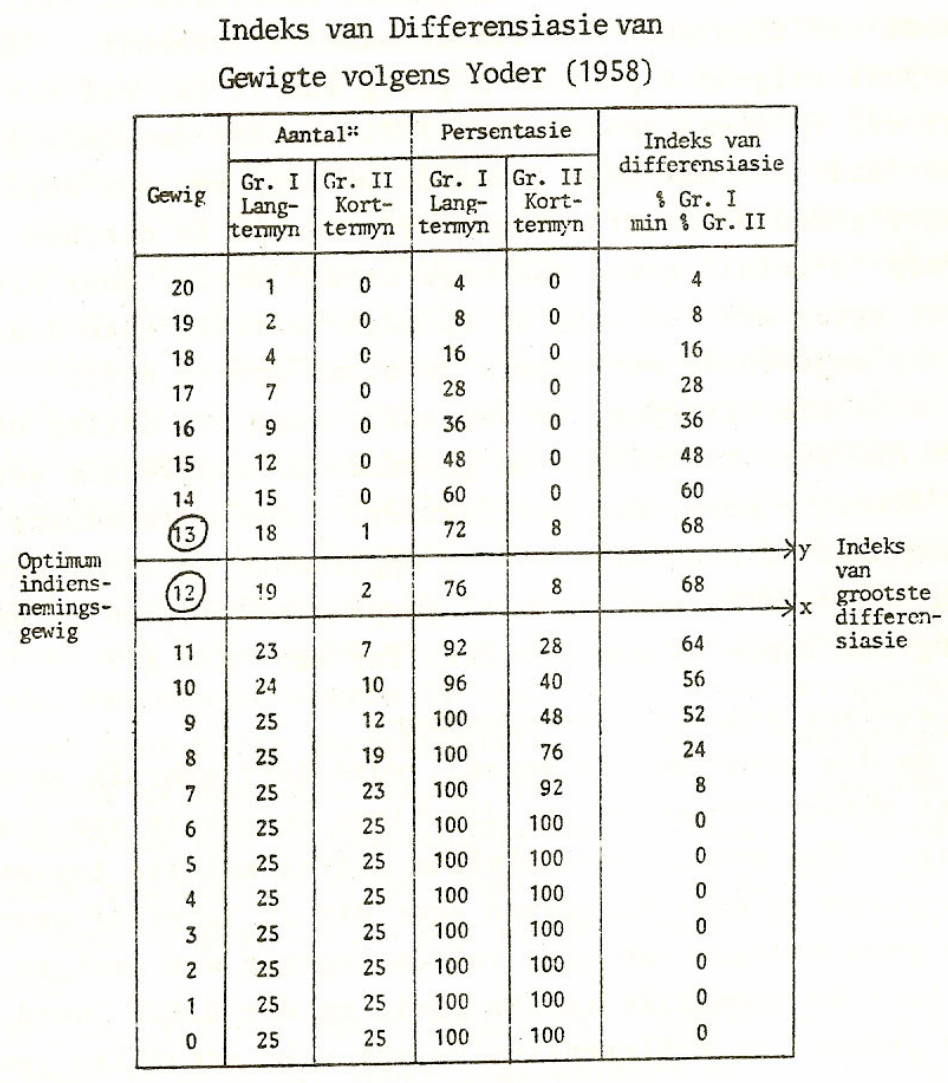

*Kumrulaticre getalle gebruik.

Die skeidslyn x in Figuur 4 en Tabel 12 verteenwoordig die geval waar die afsnygewig as 12 beskou word. Daarenteen verteenwoordig skeidslyn y in Figuur 4 en Tabel 12 die posisie waar die afsnygewig as 13 beskou word. Die verskil tussen die resultate wat verkry word deur die aanwending van die G.A.V., is egter so klein dat enige van die twee gewigte as afsnypunt gekies kan word.

In hierdie studie is daar besluit op 'n gewig van 13 as afsnypunt, aangesien dit die waarskynlikheid dat gewensde werknemers in diens geneem sal word met die gebruik van die G.A.V. effens vergroot.

Dit is egter nie altyd absoluut noodsaaklik om uitsluitlik gebruik te maak van die optimum afsnygewig nie. As die gehalte werknemers en die seleksieratio nie te hoog is nie, kan hierdie gewig heelwat verlaag word. In die geval waar 'n laer gewig as afsnypunt gekies 
word, moet die bestuur bewus wees van die groter risiko wat daar bestaan om ongewensde werknemers in diens te neem.

\section{Praktiese toepassing van afsnygewig}

Met die keuse van 13 as afsnygewig word daar dus geïmpliseer dat dit die beste skeidingspunt tussen lang- en korttermyn werknemers is. Vir voorspellingsdoeleindes kan persone met 'n gewig van 13 dus beskou word as potensiële langtermyn werknemers en persone met 'n gewig van 12 of onder as 'n groter risiko in soverre dit lengte van diens betref.

In Figuur 5 word die verhouding tussen die lang- en korttermyngroepe aangetoon ten opsigte van die afsnygewig van 13.

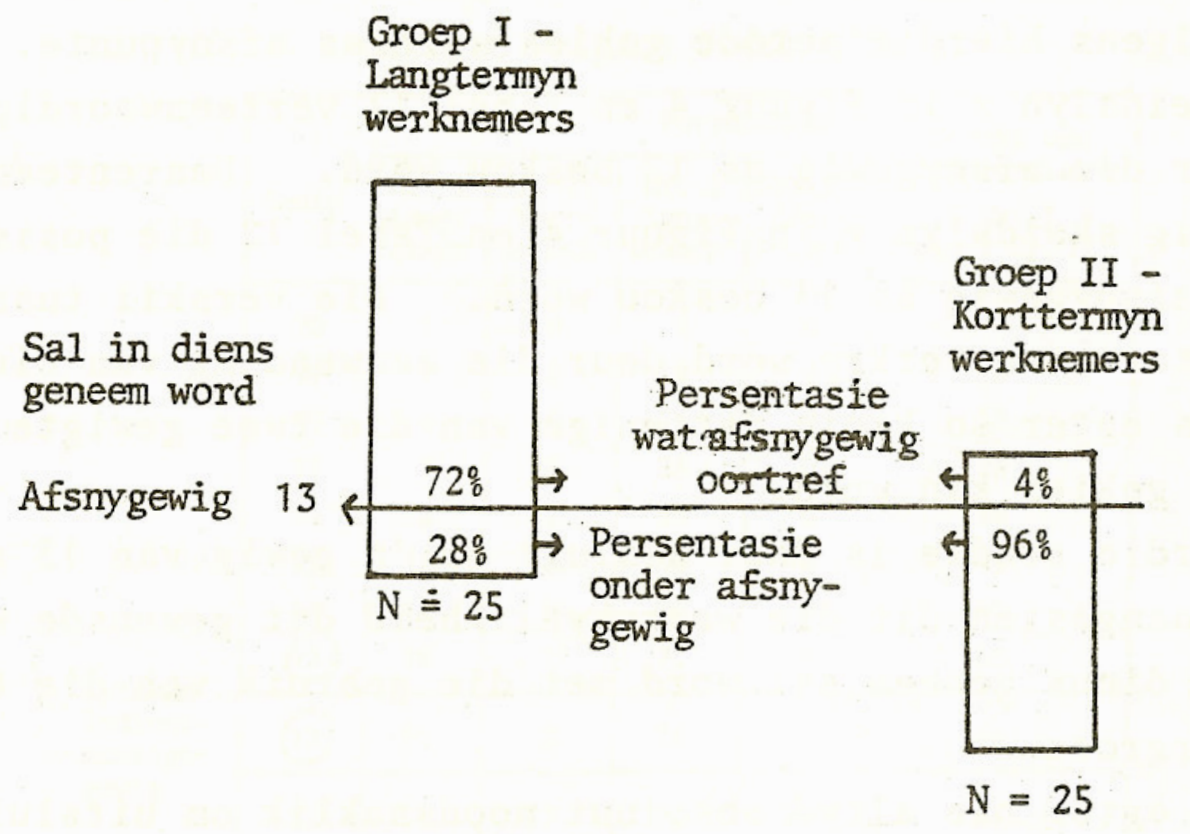

\section{Figurux 5. Verhouding van gewensde en ongewensde werknemersgroepe ten opsigte van die afsnygewig}

Volgens Figuur 5 is dit duidelik dat, met behulp van die G.A.V. en 'n berekende afsnygewig van 13, $72 \%$ langtermynwerknemers in diens geneem word en slegs $4 \%$ korttermynwerknemers. Daarteenoor sal daar $28 \%$ van die gewensde langtermynwerknemers en $96 \%$ ongewensde korttermynwerknemers verwerp word.

Soos voorheen genoem, sal die G.A.V. die beste as seleksiewerktuig funksioneer as die optimum afsnygewig gebruik word as die minimum gewig vir indiensname. Tog kan die minimum gewig opgeskuif word as daar baie en goeie applikante is. As ' $n$ bepaalde 
werkgewer egter in die posisie is waar hy nie die nodige keuse by seleksie kan uitoefen nie, kan die afsnygewig desnoods verlaag word. 'n Tabel soos Tabel 12 wat opgestel is om indekse van differensiasie daar te stel, sal in sulke gevalle baie waardevol wees aangesien dit die relatiewe voorspellings-effektiwiteit (d.w.s. die indeks van voorspellingsvermoë) aangee wat verwag kan word as ander afsnypunte gebruik word.

Tabel 12 toon aan dat as 'n afsnygewig van 12 in plaas van 13 gebruik word, word daar wat hierdie studie betref, 'n addisionele $4 \%$ gewensde werknemers in diens geneem teenoor 'n gelyke persentasie ongewensde werknemers. Aan die bevindings in hierdie studie sal dit geen noemenswaardige verskil maak as dié afwaartse verskuiwing van die minimum gewig vir indiensname geïmplementeer word nie, aangesien die maksimum differensiasie ook op hierdie punt voorkom. As die afsnygewig egter 12 was en dit moes afgeskuif word na 11, sal daar slegs 'n addisionele $16 \%$ gewensde werknemers teenoor $20 \%$ ongewensde werknemers in diens geneem word. Net so sal daar $12 \%$ minder gewensde werknemers teenoor $4 \%$ minder ongewensde werknemers in diens geneem word as die afsnygewig van 13 na 14 verhoog word. In beide gevalle is daar egter ' $\mathrm{n}$ daling in voorspellings-effektiwiteit soos aangetoon word deur die laer indeks van differensiasie vir die gewigte 14 en 11 as vir die gewig 13.

\section{KONSTRUKSIE VAN DIE GEWEEGDE AANSOEKVORM}

Nadat die gewigte vir die verskillende onderskeidende items ontwikkel is en besluit is op 'n spesifieke afsnygewig, bly die praktiese konstruksie en aanwending van die G.A.V. nog oor.

Die G.A.V. moet al die inligting inwin wat voorheen deur die tradisionele aansoekvorm verkry is, maar moet daarby nog 'n addisionele funksie vervul. Dit bemoeilik die administrasie van die G.A.V. om die biografiese items wat wel differensieer tussen gewensde en ongewensde werkers, uit te soek tussen die ander inligting wat om spesifieke redes benodig word (byvoorbeeld inligting wat deur die staat vereis word).

\section{Voorbeeld van 'n moontlike geweegde aansoekvorm}

Om die bogenoemde probleem te oorkom en 'n nette geïntegreerde voorkoms aan die G.A.V. te verleen, is daar besluit om dit soos volg aan te bied: Al die iteminformasie wat benodig word vir die gewigsonderskeiding word saamgegroepeer op een bladsy van die G.A.V. en 'n masker word dan gebruik (soos in Figuur 6 aangetoon) om die gewigte aan elke item 
direk toe te ken. Die masker bevat venstertjies wat ooreenstem met die posisie wat elke item op die G.A.V. inneem. Gewigte vir elke antwoordkategorie word op die masker teenoor die betrokke venstertjie aangebring. Figuur 7 is 'n voorbeeld van 'n moontlike uiteensetting van items in 'n G.A.V. vir 'n maklike gewigstoekenning. Die ruimtes wat in Figuur 7 gelaat word vir die applikante om hulle antwoorde in te vul, korrespondeer met spesifieke venstertjies op die masker waarlangs die gewigte aangebring is. Aan die regterkant van die venstertjie word die gewig wat deur die applikante vir elke item behaal is, aangedui. Die totaal van hierdie toegekende gewigte verskyn aan die onderent van die masker.

As daar 'n standaard aansoekvorm dwarsdeur die hele organisasie gebruik word om uniformiteit te bevorder, hoef daar nie met die G.A.V. wat vir 'n spesifieke groep werknemers ontwikkel is, van hierdie beginsel afgewyk te word nie. In so 'n geval kan die bladsy of twee waarop die biografiese items verskyn, net as 'n addisionele bylaag aan die oorspronklike vorm geheg word. As die G.A.V. egter vir die hele onderneming ontwikkel is soos in hierdie studie, is daar geen probleme nie.

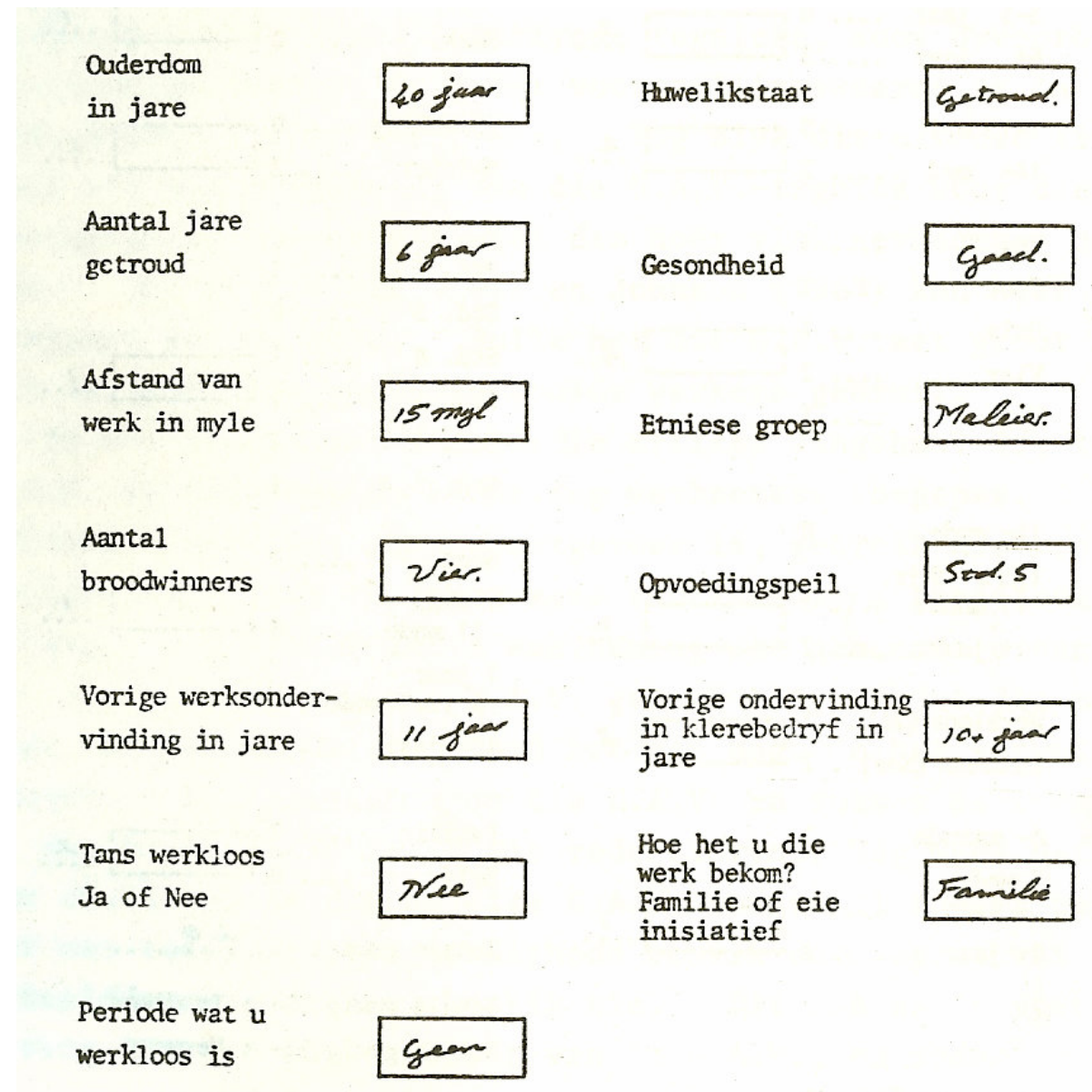

Figurur 6. Masker 


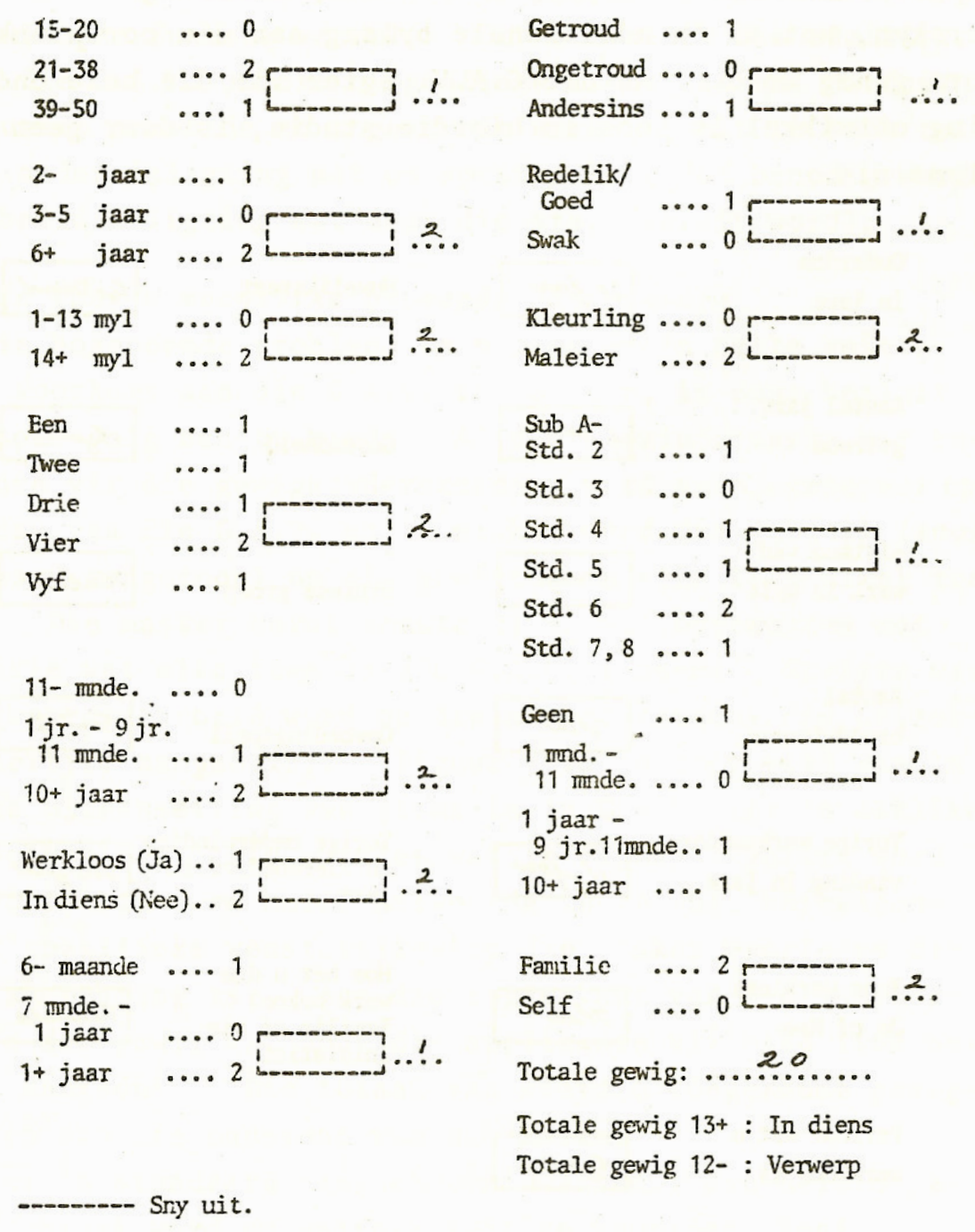

Figurur 7. Geweegde Aansoekvormbladsy

\section{TOEPASSING VAN DIE GEWEEGDE AANSOEKVORM}

Na aanleiding van 'n wye literatuurstudie, wys Schuh (1967) daarop dat daar bykans geen perke aan die aanwendingsmoontlikhede van die G.A.V. is nie. Guion en Grottier (1965) se navorsingsresultate dui byvoorbeeld daarop dat geeneen van die ander meer wetenskaplik verfynde tegnieke, soos byvoorbeeld sielkundige toetse, 'n beter voorspellingswaarde as 'n goed ontwikkelde G.A.V. lewer nie. Tog blyk dit uit die literatuur dat die toepassing van die G.A.V.-tegniek voor die laat sestigerjare meerendeels tot die hoër vlak werknemers beperk was. Die studie van Scott en Johnson (1967) kan hier as 'n keerpunt beskou word. Hulle het die G.A.V. met groot sukses vir die seleksie van ongeskoolde werkers gebruik. 
In die studie wat in hierdie artikel aangehaal is, is die G.A.V. op ongeskoolde kleurling werknemers toegepas. Die organisasie waar die studie uitgevoer is, gebruik die voorgestelde G.A.V. met 'n groot mate van sukses om arbeidsomset te bekamp. 'n Interessante waarneming wat genoemde organisasie met die gebruik van die G.A.V. gemaak het, is dat dit met verloop van tyd duidelik geword het dat daar 'n hoë korrelasie tussen 'n hoë prestasie op die G.A.V. en sukses as toesighouer in die organisasie is. Die rede hiervoor mag wees dat sekere van die items in die huidige G.A.V. onderskei tussen persone wat oor toesighouershoedanighede beskik en diegene wat nie tot dieselfde mate daaroor beskik nie. Dit kan as 'n sterk motivering vir die ontwikkeling van 'n G.A.V., om sodanige kriterium te voorspel, beskou word.

'n Baie belangrike vraag wat na aanleiding van die toepassing van die G.A.V. ontstaan, is of die items wat daarin opgeneem is, konstant bly oor 'n onbepaalde tydperk ten opsigte van hulle vermoë om byvoorbeeld langtermyndiens te voorspel. As dit wel die geval is dat items nie stabiel bly in hul voorspellingskapasiteit nie, ontstaan 'n verdere vraag onwillekeurig: hoe dikwels moet die G.A.V. herweeg word?

Daar word veral ses studies tot die middel van die sestiger jare in die literatuur gevind wat data oor kruisvalidasie bevat wat lig op hierdie aspek werp. Al ses studies toon 'n duidelike konstante daling in die voorspellingsvermoë van die ingeslote biografiese faktore. Figuur 8, wat 'n samevatting van hierdie studies is, illustreer die geleidelike daling in die voorspellingsvermoë wat in die studies gevind is baie goed. Na aanleiding van die gegewens in Figuur 8, kan dit sterk aanbeveel word dat die items van die G.A.V. tweejaarliks (die presiese periode sal afhang van die arbeidsmark, die ekonomie en baie ander faktore wat in die besondere situasie geld) vir veranderings wat gedurende die periode kan intree, nagegaan en aangepas word, daar die studie van Wernimont (1962) daarop dui dat die voorspellingsvermoë van die G.A.V. 'n geldigheidskoëffisiënt van so laag as ,075 na die derde jaar van aanwending met dieselfde biografiese items, kan behaal. Volgens al ses studies wat in Figuur 8 saamgevat is, is die laagste geldigheidskoëffisiënt van die G.A.V. ( $r=325)$ na twee jaar van aanwending met dieselfde biografiese items. Daarom is besluit om by die organisasie waar die studie uitgevoer is, aan te beveel dat die voorgestelde G.A.V. se items tweejaarliks nagegaan en desnoods herweeg moet word. 


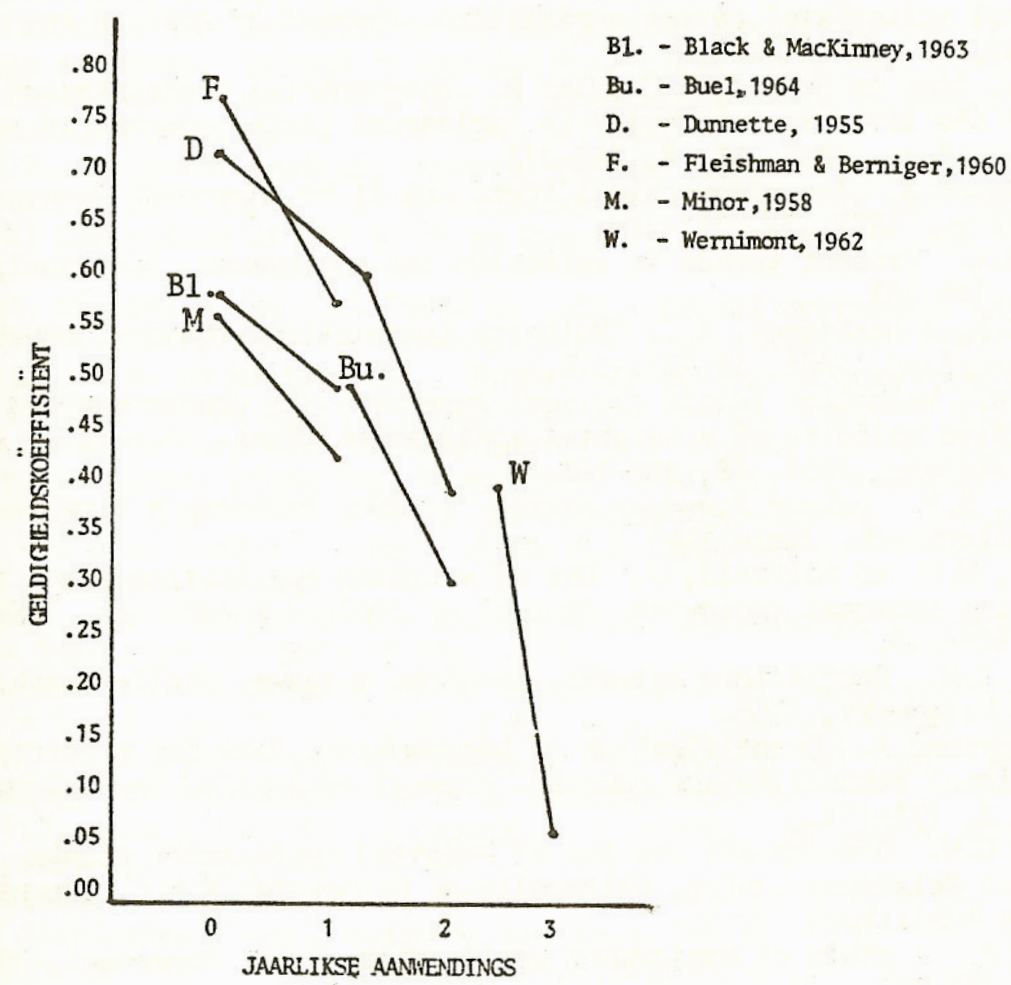

Figurur 8. Die daling in voorspellingsvermoë wat voorkom oor herhaalde aanwendings met dieselfde aansoekvormitems. (Schuh, 1967).

\section{OPSOMMING}

Vereenvoudigde prosedures vir die ontwikkeling van ' $n$ geweegde aansoekvorm ter bekamping van arbeidsomset onder gekleurde werknemers in die klerasiebedryf, word sistematies bespreek.

\section{VERWYSINGS}

Albright, Lewis E. en Glennon, J .R. Personnel history correlates of physical scientists' career aspirations. Journal of Applied Psychology, 1961, 45, 5, 281-284.

Anastasi, Anne en Schaefer, Charles E. Biographical correlates of artistic and literary creativity in adolescent girls. Journal of Applied Psychology, 1969, 53, 4, 267-273.

Asher, James J. The biographical item: can it be improved? Personnel Psychology, 1972, 25, 251-269.

Bills, M.A. Present trends in selection for employment. Personnel, 1939, 15, 148-193. 
Black, G.B. \& MacKinney, A.C. Validity information exchange. Personnel Psychology, 1963, 16, 217-219.

Buel, W.P. Voluntary female clerical turnover: the concurrent and predictive validity of a weighted application blank. Journal of Applied Psychology, 1964, 48, 180-183.

Cilliers, S.P. Labour Turnover in the Clothing Industry - Final Report. Stellenbosch, Junie 1968.

Dunnette, M.D. en Maltzeld, J. Use of weighted application blank in hiring seasonal employees. Journal of Applied Psychology, 1955, 39, 5, 308-310.

Du Toit, J.M. Statistiese metodes, hersiene uitgawe, Stellenbosch: Kosmer Uitgewers, 1966.

Ehrle, Raymond A. Quantification of biographical data for predicting vocational rehabilitation success. Journal of Applied Psychology, 1964 48, 3, 171-174.

England, G.W. Development and Use of Weighted Application Blanks. Industrial Relations Centre, University of Minnesota: W.M.C. Browns Company Publishers, 1961.

Everett, A. A study of employment application forms. Personnel, 1939, 13, 194-207.

Fleishman, E.A. en Berniger, J. One way to reduce office turnover, Personnel, 1960, 37, 6369.

Flippo, Edwin B. Principles of Personnel Management. Derde uitgawe, McGraw-Hill, 1971.

Glennon, J.R., Albright, L.E. en Owens, W.A. A Catalog of Life History Items. The Creativity Research Institute of the Richardson Foundation, Greenboro: Junie 1966.

Goldsmith, Dorothy B. The use of the personnel history blank. Journal of Applied Psychology, 1922, 6, 2, 149-155.

Goldstein, Irwin L. The application blank: how honest are the responses? Journal of Applied Psychology, 1971, 55, 5, 491-492.

Guion R.M. Personnel Testing. New York: McGraw-Hill, 1965.

Guion: R.M. en Grottier, R.F. Measures in personnel selection. Personnel Psychology, 1965, $18,2$.

Harrell Thomas W. The validity of biographical data-items for food company salesmen. Journal of Applied Psychology, 1960, 44, 1, 31-33.

Henry, E.R. Conference on the use of biographical data in psychology. American Psychologist, 1966, 21, 247-249.

Kahn, M.W. A factor-analytic study of personality, intelligence, and history characteristics of murderers. Proceedings of the 73rd Annual Convention of the American Psychological Association, 1965, 227-228.

Kavanagh, Michael J. en York David K. Biographical correlates of middle managers' performance. Personnel Psychology, 1972, 25, 319-332.

Kerr, Willard A. en Martin, H.L. Production of job success from the application blank. Journal of Applied Psychology, 1949, 5, 313.

Kerr, W.A. en Martin, H.L. Prediction of job success from application blank. Journal of Applied Psychology, 1950, 34, 5, 442-444.

Kerrich, J.E. The art of statistics. Presidential address to section A at the East London Congress of the S.A. Association for Advancement of Science. Julie 1965.

Kretschmer, E.S. Simposium oor Arbeidsomset. Sielkundige Instituut van die Republiek van Suid-Afrika, 1966.

McGrath, James J. Improving credit evaluation with a weighted application blank. Journal of Applied Psychology, 1960-61, 44-45, 325.

Meredith, William M. Basic Mathematical and Statistical Tables for Psychology and Education. New York: McGraw-Hill, 1967.

Minor, F.J. The prediction of turnover of clerical employees. Personnel Psychology, 1958, 11, 393-402. 
Mood, Alexander M. en Graybill, Franklin A. Introduction to the Theory of Statistics. Tweede uitgawe, New York: McGraw-Hill, 1966, 317-319.

Mosel, J.N. en Wade, R.R. A weighted application blank for reduction of turnover in department store salesclerks. Personnel Psychology, 1951, 4, 177-184.

Mosier, C.1., Cureton, E.E., Katzell, A.A. en Wherry, R.J. The need and means of crossvalidation. Educational and Psychological Measurement, 1951, 11, 5-28.

Rudolph, Gerhardus J. Oor eksakte en asimptotiese benaderde statistiese toetse. Ph.D.-tesis. Universiteit van Pretoria, Desember 1963.

Schuh, A.E. Predictability of employee tenure: A review of the literature. Personnel Psychology, 1967, 20, 133-152.

Scott, Richard D. en Johnson, Richard W. Use of the weighted application blank in selecting unskilled employees. Journal of Applied Psychology, 1967, 51, 5, 393-395.

Smit, W.J., Albright, L.E., Glennon, J.R. en Owens, W.A. The prediction of research competence and creativity from personal history. Journal of Applied Psychology, 1961, $45,59-62$.

Stead, W.H. en Shartle, C.L. Occupational Counseling Techniques. New York: American Book Co., 1940, 255.

Stone, C.H. en Kardall, W.E. Effective Personnel Selection Procedures. Englewood Cliffs, New Jersey: Prentice-Hall, 1958.

Tanofskry, Robert R., Shepps, Ronald en O'Neill, Paul J. Pattern analysis of biographical prediction of success as an insurance salesman. Journal of Applied Psychology, 1969, 53, 136-139.

Welch, Josephine en Stone, Harold C. How to Develop a Weighted Application Blank. Industrial Relations Centre, Minnesota: William C. Brown Company, tweede uitgawe, 1961.

Wernimont, P.F. Re-evaluation of a weighted application blank for office personnel. Journal of Applied Psychology, 1962, 46, 417-419.

Wilks en Fisher, J. Methods and tables for test of contingency. Annals of Human Genetics, 1965-67, 21, 397-410.

Woolf, B. The log likelihood ratio test (Ci-test). Annals of Human Genetics, 1965, 21, 397.

Yoder, D., Henneman, H.G., Turnbull, J.G. en Stone, C.H. Handbook of Personnel Management and Labour Relations. London: McGraw-Hill, 1958. 
